\title{
Efeito das políticas de provimento ao cargo de diretor na gestão escolar
}

\author{
Bruno Sendra de Assis 1 \\ Nelson Marconi 1 \\ 1 Fundação Getulio Vargas / Escola de Administração de Empresas de São Paulo, São Paulo / SP - Brasil
}

\begin{abstract}
A liderança do diretor escolar constitui um dos fatores centrais para garantir um ambiente educacional adequado ao processo de ensino-aprendizagem. No entanto, ainda há poucos estudos que analisam os determinantes da atuação do diretor. O presente estudo avaliou o potencial efeito das políticas de seleção de diretores sobre a percepção do corpo docente em relação à liderança e ao clima escolar. Os fatores foram criados a partir das respostas aos questionários de contexto aplicados do Sistema Nacional de Avaliação da Educação Básica (Saeb) de 2013 e de 2015. Também foram analisadas as legislações de provimento ao cargo de diretor nos 26 estados e no Distrito Federal. Os resultados apontaram uma diferença estatisticamente significante entre o grupo de escolas que realizou o "concurso público apenas" e o "processo seletivo e eleição", em relação ao grupo que adotou a modalidade de "indicação apenas". Todavia, a alta variação observada nos coeficientes de clima e de liderança entre os entes federados evidencia que o contexto local afeta a percepção do corpo docente sobre estas variáveis. Isso demonstra que, além do processo seletivo, é importante considerar as características de cada localidade para a seleção dos profissionais com as competências e as habilidades apropriadas aos desafios do cargo, que possam vir a contribuir com melhores resultados educacionais dos estudantes.
\end{abstract}

Palavras-chave: políticas educacionais; gestão escolar; provimento ao cargo de diretor; liderança; clima escolar.

\section{Efecto de las políticas de selección de directores en la gestión escolar en Brasil}

El liderazgo del director escolar es uno de los factores centrales para asegurar un ambiente educativo apropiado al proceso de enseñanza-aprendizaje. Sin embargo, aún son pocos los estudios que analizan los determinantes del desempeño del director. El presente estudio evaluó el efecto potencial de las políticas de selección de directores sobre la percepción del profesorado en relación con el liderazgo y el clima escolar. Los factores se crearon a partir de las respuestas a los cuestionarios contextuales aplicados por el Sistema Nacional de Evaluación de la Educación Básica (Saeb) de 2013 y 2015. También se analizó la legislación que reglamenta el cargo de director en los 26 estados brasileños y el Distrito Federal. Los resultados mostraron una diferencia estadísticamente significativa entre el grupo de escuelas que realizó el "concurso público" y el "proceso de selección y elección", en relación con el grupo que adoptó la modalidad de "nominación política". Sin embargo, la alta variación observada en los coeficientes de clima y liderazgo entre las entidades federativas evidencia que el contexto local afecta la percepción del cuerpo docente sobre estas variables. Por lo tanto, además del proceso de selección, es importante considerar las características de cada localidad para la selección de profesionales con las competencias y habilidades adecuadas a los desafíos del puesto, que pueden contribuir a mejores resultados educativos para los estudiantes.

Palabras clave: políticas educativas; gestión escolar; selección de directores; liderazgo; clima escolar.

\section{The effect of policies for filling school principal positions on school management in Brazil}

Leadership by a school principal is one of the key factors for ensuring an educational environment conducive to the teaching-learning process. Nevertheless, only a handful of studies have analyzed the determinants of principals' performance. This study evaluated the potential effect of principal selection policies on teacher perceptions of principal leadership and school climate. The factors were created based on responses to the National Basic Education Assessment System (Sistema Nacional de Avaliação da Educação Básica - Saeb) contextual questionnaires applied in 2013 and 2015. The legislation for filling school principal positions in the 26 states and the Federal District was also analyzed. The results showed a statistically significant difference between the group of schools that carried out "civil service examination only" and "selection process and election" compared to the group that adopted the "appointment only" modality. However, the high variation observed in the climate and leadership coefficients between the federative entities reveals that the local context affects teacher perceptions of these variables. This demonstrates that in addition to the selection process, it is important to consider each locality's characteristics to select professionals with competencies and skills appropriate to the position's challenges, which may contribute to better educational outcomes for students. Keywords: educational policies; school management; filling school principal positions; leadership; school climate. 


\section{AGRADECIMENTOS}

Agradecemos os comentários de Joyce Soares Rodrigues Petrus, Paula Baptista Jorge Louzano e Pedro Feliú Ribeiro, que foram fundamentais para a elaboração deste artigo.

\section{INTRODUÇÃO}

O objetivo deste estudo é analisar se as diferentes modalidades de seleção de diretores das escolas públicas estaduais de ensino básico interferem na percepção do corpo docente sobre a liderança do diretor e o clima escolar onde atuam. Ambos são considerados fatores centrais de escolas eficazes para garantir um ambiente educacional propício à cooperação e aos objetivos pedagógicos (Abrucio, 2010; Alves \& Franco, 2008; Teddlie \& Reynolds, 2000). Foi escolhido o processo seletivo como objeto de análise porque permite, quando bem desenhado, identificar se os candidatos possuem as competências e as habilidades necessárias para exercerem uma função tão complexa. Os microdados foram obtidos nos questionários de contexto do Sistema Nacional de Avaliação da Educação Básica (Saeb) de 2013 e de 2015, sendo também consultadas as legislações de provimento ao cargo de diretor nos 26 estados e no Distrito Federal.

O método utilizado para a criação dos fatores de liderança do diretor e de clima escolar foi a Teoria de Resposta ao Item (TRI), de Samejima (1969), adaptando-se os construtos desenvolvidos por Oliveira e Waldhelm (2016). As questões relacionadas no Saeb foram consolidadas em um indicador para liderança e um para clima escolar, que representam a percepção média do corpo docente por escola. Em seguida, aplicou-se um modelo de regressão linear múltipla (Wooldridge, 2011) para responder se "a forma de provimento ao cargo de diretor está associada à percepção do corpo docente sobre a liderança exercida pelo diretor e o clima escolar"? O efeito observado nos dois modelos confirmou a hipótese inicial do estudo, de que existe diferença na percepção de liderança e de clima entre as escolas que adotaram modalidades distintas de seleção de diretores.

$\mathrm{Na}$ análise dos marcos legais de provimento ao cargo de diretor, observou-se quais são as modalidades regulamentadas por Unidade Federativa (UF) e no Distrito Federal, bem como sua correspondência com as respostas espontâneas nos questionários do Saeb. Constatou-se uma grande disparidade entre os processos de formulação (avaliada através das legislações) e de implementação (avaliada por meio dos microdados) destas políticas em cada local, sobretudo pela alta incidência do critério de "indicação apenas", ainda que tenham sido regulamentadas outras formas de seleção. Por outro lado, os dois modelos de análise sugerem que a adoção de critérios técnicos e/ou participativos para a escolha do diretor escolar favorecem a percepção de liderança e de clima, condizente com o disposto no Plano Nacional de Educação (PNE, 2014). Na próxima seção, será apresentado o referencial teórico utilizado, com destaque para as concepções sobre gestão escolar, liderança, clima, seleção de diretores e a relação entre tais variáveis. Na sequência serão descritos os procedimentos metodológicos da pesquisa documental e os dois modelos desenvolvidos para a liderança do diretor e o clima escolar, seguidos pela análise dos resultados e conclusões acerca do objeto estudado. 


\section{REFERENCIAL TEÓRICO}

Os diretores possuem um papel significativo tanto na aprendizagem como no ambiente educacional (Abrucio, 2010). Embora o desempenho acadêmico seja o critério central de qualidade escolar, é fundamental que o modelo de gestão atue na melhoria do processo organizacional como um todo, criando condições favoráveis ao conjunto de atores deste sistema. A literatura inglesa e a americana empregam o conceito de School Effectiveness Research para identificar os fatores associados aos melhores resultados acadêmicos dos alunos, incluindo políticas e práticas internas da escola (Soares, 2004). Para isso, segundo Alves e Franco (2008), é preciso controlar a influência externa do nível socioeconômico e cultural das suas famílias, incluindo a trajetória escolar (defesagem idade-série) e a rede de ensino onde estudaram (pública ou privada).

A importância do perfil do diretor para o alcance de bons resultados de aprendizagem é destacada desde os primeiros estudos sobre o efeito-escola (Teddlie \& Reynolds, 2000). Conforme citado na introdução, consideramos dois aspectos importantes de tal perfil em nossa análise nesse artigo: a liderança e a sua influência sobre o clima escolar. Portanto, discutiremos a seguir estudos que analisam o efeito do processo de escolha dos diretores sobre os resultados de aprendizagem e, posteriormente, a relação entre a modalidade de seleção escolhida e a percepção dos professores sobre a liderança e o clima escolar, sendo que este último ponto constitui o foco de nosso estudo.

\subsection{A relação entre o processo de escolha dos diretores e o desempenho escolar}

Para justificar a relevância deste estudo, iniciaremos a discussão teórica apresentando alguns artigos que analisaram a relação entre as formas de provimento do cargo de diretor e o desempenho escolar. Neste sentido, Oliveira e Carvalho (2015) argumentam que a alta incidência do critério de escolha do diretor por "indicação apenas" é parte da tradição patrimonial brasileira, cujo risco é desconsiderar capacidades educacionais ou de gestão. Nas análises realizadas, esta modalidade representou, aproximadamente, $20 \%$ da variação negativa nas notas de matemática dos alunos do $5^{\circ}$ ano em três edições da Prova Brasil. Já Pereda, Lucchesi, Mendes e Bresolin (2015) verificaram um desempenho superior dos alunos do $5^{\circ}$ ano e do $9^{\circ}$ ano nas notas de matemática da Prova Brasil de 2007 e de 2011, nas escolas que realizaram o "processo seletivo e eleição", o "concurso público apenas" e o "processo seletivo apenas", quando comparadas àquelas com "indicação apenas".

Lück (2011) corrobora a visão crítica sobre a escolha de diretores mediante “indicação apenas", em detrimento de outras competências necessárias à formação e à aprendizagem dos alunos, condizente com a literatura. De acordo com o Instituto Brasileiro de Geografia e Estatística (IBGE, 2015), esta modalidade é a menos recomendada para se avançar no PNE (2014), devido às práticas clientelistas comuns (privilégios individuais em troca de votos), sem qualquer consulta à comunidade escolar ou garantia de qualificação técnica dos candidatos. Os dois autores reportaram problemas semelhantes no critério de "eleição apenas", cujos riscos são semelhantes ao processo eleitoral. Entretanto, os adeptos desta modalidade defendem a possibilidade de envolver diferentes segmentos na busca por uma liderança escolar mais efetiva, a alternância de poder, a melhoria do clima organizacional e a transparência nas relações (Maia \& Manfio, 2010).

O "concurso público apenas" é considerado mais técnico e transparente segundo Lück (2011), porém limita a possibilidade de substituição nesse cargo, caso seja necessário, e a participação da comunidade escolar. O "processo seletivo apenas" e o "processo seletivo e eleição", por sua vez, 
permitem verificar melhor as competências e as habilidades dos candidatos por meio de entrevistas, exame de certificação, prova de conhecimentos, prova de títulos, carta de intenções e planos de gestão para a avaliação da comunidade escolar. Este último é comum em países com sistemas educacionais de alto desempenho e permite maior accountability na gestão. As vantagens da modalidade mista “processo seletivo e eleição" também são destacadas por Ghanem (1995) e Libâneo (2001).

Embora haja um aparente consenso sobre as consequências negativas da "indicação apenas", Gremaud, Pazello e Maluf (2015) não observaram um impacto relevante deste método no desempenho educacional dos alunos, mediante o potencial efeito de tal opção sobre a habilidade gestora dos diretores. Os modelos analisados tiveram pouca diferença nas notas médias de matemática entre as escolas que alteraram as suas modalidades de seleção, a partir dos microdados da Prova Brasil de 2007 a 2011.

Pereda et al. (2015) concluíram que o processo seletivo impacta o aprendizado e/ou o rendimento acadêmico por meio do perfil do diretor escolhido. A permanência no cargo na mesma escola entre 05 e 15 anos e a promoção de ações de formação continuada para professores tiveram resultados mais consistentes em diferentes análises. Dessa maneira, a maioria dos estudos citados corrobora o argumento de que, no caso brasileiro, a forma de escolha do diretor influi sobre o desempenho escolar.

\subsection{A relação entre a percepção sobre liderança e clima escolar e o processo de escolha de diretores escolares}

$\mathrm{Na}$ literatura sobre gestão escolar, a liderança do diretor e o clima escolar, enquanto um ambiente de cooperação voltado ao processo de ensino-aprendizagem, são destacados entre as principais características para diferenciar o desempenho dos alunos (Levine \& Lezotte, 1990; Rutter, Maughan, Mortimore, Ouston \& Smith, 2008; Sammons, 2008; Teddlie \& Reynolds, 2000).

Liderança é sinônimo de escola eficaz e o bom diretor é capaz de exercê-la de maneira firme, objetiva, estável, adequada, acadêmica e compartilhada com a equipe (Mortimore, Sammons \& Ecob, 1988; Rutter et al., 2008; Sammons, 2008; Teddlie \& Stringfield, 1993). A liderança representou $25 \%$ da variância total na aprendizagem dos alunos, quando analisados os fatores intraescolares. Se comparada à diferença interescolar, o percentual foi 3\% a 5\% (Leithwood \& Jantzi, 2009). No Brasil, a liderança do diretor também é um dos aspectos comuns associados ao bom desempenho escolar (Abrucio, 2010; Alves et al., 2015; Alves \& Franco, 2008; Lück, 2009).

Alves et al. (2015) operaram três construtos de liderança: administrativa, pedagógica e participativa. Os resultados obtidos apresentaram uma alta consistência em relação ao desempenho escolar. A primeira enfatiza os recursos financeiros para o funcionamento e manutenção da escola, bem como os problemas que afetam a sua rotina. A segunda refere-se à habilidade do diretor para estruturar e implementar metas e projetos compartilhados para melhoria do ensino, o estímulo à capacitação docente e a legitimidade junto à equipe pedagógica. A última inclui o método de seleção dos diretores, a composição do conselho escolar, a frequência de reuniões do conselho de classe e o modo de elaboração do projeto político pedagógico.

De acordo com Oliveira (2015), as discussões sobre as tipologias de liderança escolar são frequentes, embora não consensuais. Nos Estados Unidos, destacam-se a Liderança Transformacional (desenvolvimento humano e organizacional) e a Instrucional (interação com os professores para guiar o cumprimento do currículo e a aprendizagem). Marks e Printy (2003) propuseram agregar 
as características da gestão pedagógica e relacional do diretor, o que foi denominado de Liderança Integrada. Esse conceito foi corroborado por Oliveira e Carvalho (2015) e Urick e Bowers (2014), que sugeriram contemplar ainda os fatores de interação com o contexto e os outros agentes escolares. Isso porque os diretores tendem a adaptar a sua atuação conforme as necessidades dos professores e dos alunos, bem como as políticas e normativas de responsabilização locais, combinando diferentes tipos de liderança ao desempenharem sua função.

O clima escolar, por sua vez, é considerado o maior fator explicativo de diferenciação entre escolas com melhor desempenho por Abrucio (2010). O autor enfatiza a importância do trabalho em equipe, coesão, comprometimento, participação, corresponsabilização e motivação, destacados também por Lück (2009). Para Sammons (2008), o ethos de uma escola é determinado pelo modo como seus profissionais trabalham juntos, por valores e objetivos comuns e pelo ambiente de aprendizagem entre os alunos. Teddlie e Reynolds (2000) acrescentam o compartilhamento da missão e da visão, o senso comunitário e a consistência na prática curricular e na aplicação de regras e de sanções disciplinares. Em suma, quando as normas e as metas são pactuadas e a participação de todos é claramente delineada, há um clima escolar positivo.

$\mathrm{Na}$ visão de alguns autores, o clima escolar seria resultado de lideranças mais eficazes (Abrucio, 2010; Lück, 2009), de modo que as duas variáveis estariam interligadas. Estudo de Oliveira (2015) identificou associações significativas entre os tipos de liderança e a atuação gerencial do diretor, especialmente na construção e na manutenção de um clima organizacional favorável à docência e à aprendizagem. A combinação destes fatores está alinhada ao efeito institucional de Rutter et al. (2008), com maior poder de atuação. Logo, é preciso refletir sobre os conceitos de gestão, liderança e clima escolar de modo integrado e não isoladamente, visto se tratar de uma organização social com pessoas em constante interação. A autora aponta ainda que há poucos estudos no país dedicados a compreender a percepção dos professores sobre situações que envolvem o trabalho do diretor escolar ou as relações no ambiente escolar.

Por outro lado, algumas pesquisas empíricas analisadas tratam estes fatores de maneira distinta. Ao analisar as desigualdades de aprendizado nas escolas do Brasil, a Organização das Nações Unidas para a Educação, a Ciência e a Cultura (UNESCO, 2017) construiu quatro fatores agregados: liderança, clima, características do ensino e dos professores e infraestrutura da escola. No tocante à liderança, foram analisados fatores administrativos, pedagógicos, participativos, recursos humanos, formação do diretor e experiência; sobre o clima escolar, foram contemplados fatores de coesão da equipe pedagógica, condições de funcionamento da escola, intervenções para melhoria (acesso, reprovação e abandono) e violência escolar. Concluiu-se que nas escolas onde a liderança e o clima são favoráveis, há menores chances de os alunos estarem em situação de exclusão e maiores chances de estarem no nível adequado de aprendizagem.

As características de clima escolar e de liderança do diretor também foram agrupadas em dois fatores distintos por Oliveira e Waldhelm (2016) para se estabelecer uma possível relação entre fatores intraescolares e o desempenho dos alunos do $5^{\circ}$ ano em matemática na Prova Brasil de 2013. Neste estudo, os autores utilizaram as questões que envolvem as relações pessoais entre professores e diretores e a atuação pedagógica e administrativa dos diretores nas escolas, resultando na criação do Índice Médio de Liderança do Diretor. Assim, as variáveis analisadas, que poderiam 
identificar diferentes perfis de liderança, foram agrupadas em um mesmo fator para mensurar a percepção global dos professores sobre o tema. Ressalta-se, contudo, que nem todas as dimensões de liderança escolar estão contempladas neste índice.

Ainda neste mesmo estudo, as questões relacionadas à percepção dos professores sobre os fatores que interferem na construção de um ambiente escolar propício à aprendizagem dos alunos foram agregadas para criação do Índice Médio de Clima Escolar/Colaboração Docente, incluindo informações sobre a coesão entre os integrantes da equipe, geralmente relacionadas à atuação do diretor. Porém, também não abrangem todos os elementos que constituem o clima escolar, tais como a violência e a disciplina. O modelo desenvolvido conseguiu explicar 15,9\% da variação do desempenho dos alunos do Rio de Janeiro e reforça a importância atribuída aos fatores intraescolares na literatura.

Os indicadores discutidos acima possibilitaram uma análise diferenciada dos impactos da forma de provimento do cargo de diretor em relação às percepções de liderança e de clima escolar, que referenciaram a criação das variáveis dependentes no modelo empírico adotado neste artigo. $\mathrm{Na}$ próxima seção, apresentaremos nossas hipóteses e discutiremos a metodologia adotada na busca de sua comprovação.

\section{HIPÓTESES E PROCEDIMENTOS METODOLÓGICOS}

Com base nesta análise teórica inicial, apresentamos as duas hipóteses principais deste trabalho:

1) Há diferença entre a percepção média do corpo docente sobre a liderança do diretor nas escolas que adotam modalidades distintas para a escolha dos diretores; e

2) Há diferença entre a percepção média do corpo docente sobre o clima escolar nas escolas que adotam modalidades distintas para a escolha dos diretores.

Na busca da comprovação de tais hipóteses, foram desenvolvidos os procedimentos metodológicos descritos a seguir.

A primeira etapa da análise empírica deste estudo compreendeu um levantamento, em dezembro de 2016, nos canais oficiais de internet do Poder Legislativo e do Executivo, das regulamentações sobre as políticas estaduais de seleção de diretores escolares nas 26 UFs brasileiras e no Distrito Federal. Identificou-se um rico acervo de leis e normas para análise, que foram classificadas em três grupos: Planos Estaduais de Educação (PEE); planos de carreira e estatutos dos professores ou dos profissionais da educação; e sistemas estaduais de ensino, gestão democrática e leis específicas sobre a matéria. As modalidades de seleção atribuídas reproduzem as mesmas respostas dos questionários do Saeb, para garantir a comparação entre os estágios de formulação e implementação destas políticas. O resumo das leis analisadas está disponível no Apêndice.

Em seguida, foram analisados os microdados dos questionários contextuais do Saeb de 2013 e de 2015, respondidos por diretores e professores das escolas públicas estaduais que lecionavam as disciplinas de Matemática ou de Língua Portuguesa para turmas do $5^{\circ}$ ano e do $9^{\circ}$ ano do Ensino Fundamental, bem como da $3^{\circ}$ série do Ensino Médio. Dentre as 40.792 escolas elegíveis, 39.098 diretores responderam à questão específica sobre a forma de acesso ao cargo (96\%). Para garantir representatividade amostral, incluíram-se somente os dados dos professores que responderam as dez questões selecionadas sobre liderança (191.073) ou as quatro sobre clima escolar (192.108), 
representando uma média próxima a 5 professores por escola. Mantiveram-se as observações incompletas em todas as variáveis para fins de análise descritiva. Obteve-se, assim, uma amostra final de 39.456 escolas.

Neste estudo, foi utilizado o modelo estatístico de Teoria de Resposta ao Item (TRI) para construção dos indicadores de clima e liderança, a fim de obter medidas de construtos latentes com base em fatores dicotômicos ou ordinais (Alves et al., 2015). Estes modelos são adotados frequentemente nos trabalhos educacionais devido à necessidade de avaliar os itens dos testes e estimar as habilidades dos alunos, além de permitir o uso de questões com dados incompletos para estimativa de valor do escore de interesse, o que é bastante comum nestes questionários. Por este motivo, representam uma vantagem em relação aos métodos convencionais.

Logo, a partir do conjunto de variáveis selecionadas dos questionários contextuais, as respostas dos professores foram sintetizadas em dois indicadores distintos: liderança do diretor e clima escolar. Posteriormente, tais medidas foram agrupadas ao nível da escola por sua média. Como estas variáveis são ordinais, empregou-se o modelo de Samejima (1969), que supõe a unidimensionalidade dos dados para a produção de um construto latente. A análise dos autovalores e autovetores sintetiza a matriz de correlação policórica, mais apropriada para as variáveis ordinais: "Se o primeiro autovalor é responsável por grande parte da variabilidade presente na matriz de correlação, considera-se essa suposição válida, o que justifica a síntese das variáveis em um único fator" (Alves et al., 2015, p. 61) Desse modo, foram estimados inicialmente os parâmetros dos itens e a distribuição das respostas para posterior definição dos escores dos fatores.

Na sequência, aplicou-se um modelo de regressão linear múltipla (Wooldridge, 2011), visando mensurar as variações (em termos percentuais) na percepção do corpo docente sobre os indicadores de liderança do diretor e de clima escolar, quando forma de escolha dos diretores se alterna e os demais fatores permanecem fixos. Foram estimados os efeitos para as seguintes modalidades": "concurso público apenas"; "eleição apenas"; "indicação apenas"; "processo seletivo apenas"; "processo seletivo e eleição"; "processo seletivo e indicação"; ou "outra forma". Cada modalidade foi transformada em uma variável binária e analisada simultaneamente nos modelos de liderança e de clima.

Para fins de comparação, foi escolhida como modalidade padrão o "processo seletivo e indicação", pois os valores dos coeficientes nas escolas que o adotaram estão mais próximos à média nacional de liderança e de clima escolar. Logo, os resultados das outras modalidades analisadas devem considerar esta referência. Já as respostas da modalidade "outra forma” foram descartadas devido à sua dificuldade de interpretação, pois não é possível conhecer os mecanismos de avaliação contemplados na resposta.

A escolha das variáveis dependentes ocorreu devido à sua relevância na literatura em relação aos efeitos positivos na aprendizagem. Especificamente, foram adaptados os dois construtos de Liderança do Diretor e de Clima Escolar/Colaboração Docente, elaborados por Oliveira e Waldhelm (2016), que se mostraram adequados no teste de associação entre as variáveis. Entretanto, no grupo inicial de cinco questões relacionadas ao clima, optou-se por excluir a primeira, por ter apresentado um comportamento diferente em relação à polaridade na comparação com as demais. Isso indica que elas podem não estar associadas a um único construto. Já as dez variáveis referentes à liderança foram mantidas conforme o modelo das autoras. Outra diferença, já citada, foi a utilização da TRI ao invés

${ }^{1}$ Pergunta nº 14 do questionário de contexto do Diretor no Saeb 2013 e 2015. 
do método de análise fatorial, por permitir que perfis incompletos componham a estimação destes construtos, ou seja, as variáveis com ausência de algum dado são consideradas ao invés de excluídas da análise. Os resultados obtidos estão disponíveis no Apêndice.

O Quadro 1 contém as questões utilizadas para construção dos fatores de liderança do diretor e de clima escolar. No primeiro, as opções de resposta indicam a frequência por ação e têm 5 níveis ordinais, que foram categorizados em valores de 0 a 4 . No segundo, as questões têm 4 níveis ordinais, com valores de 0 a 3. Após a estimação do traço latente, por meio da TRI, que retorna o indicador em uma escala de distribuição Normal de média zero e variância 1 (que varia de -3 a 3 pontos), as duas escalas foram transformadas para uma escala de média 50 e desvio padrão 10 , a fim de facilitar a interpretação dos dados.

\section{QUADRO 1 INDICADORES DE CLIMA ESCOLAR E DE LIDERANÇA DO DIRETOR NO SAEB 2013 E 2015}

\begin{tabular}{|c|c|c|}
\hline Fator & $\mathrm{N}^{0}$ & Questionário \\
\hline \multirow{4}{*}{ 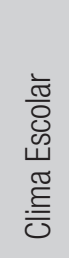 } & $53^{*}$ & Participou do planejamento do currículo escolar ou parte dele? \\
\hline & 54 & Trocou materiais didáticos com seus colegas? \\
\hline & 55 & Participou de reuniões com colegas que trabalham com a mesma série (ano) para a(0) qual leciona? \\
\hline & 56 & Participou em discussões sobre o desenvolvimento da aprendizagem de determinados alunos? \\
\hline \multirow{11}{*}{ 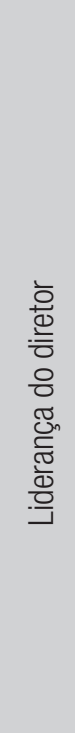 } & 57 & Envolveu-se em atividades conjuntas com diferentes professores (por exemplo, projetos interdisciplinares)? \\
\hline & 58 & O(A) diretor(a) discute metas educacionais com os professores nas reuniões. \\
\hline & 59 & $\begin{array}{l}\text { O(A) diretor(a) e os professores procuram assegurar que as questões de qualidade de ensino sejam uma } \\
\text { responsabilidade coletiva. }\end{array}$ \\
\hline & 60 & O(A) diretor(a) informa os professores sobre as possibilidades de aperfeiçoamento profissional. \\
\hline & 61 & O(A) diretor(a) dá atenção especial a aspectos relacionados com a aprendizagem dos alunos. \\
\hline & 62 & O(A) diretor(a) dá atenção especial a aspectos relacionados com as normas administrativas. \\
\hline & 63 & O(A) diretor(a) dá atenção especial a aspectos relacionados com a manutenção da escola. \\
\hline & 64 & $\mathrm{O}(\mathrm{A})$ diretor(a) me anima e me motiva para o trabalho. \\
\hline & 65 & O(A) diretor(a) estimula atividades inovadoras. \\
\hline & 66 & Sinto-me respeitado pelo(a) diretor(a). \\
\hline & 67 & Tenho confiança no(a) diretor(a) como profissional. \\
\hline
\end{tabular}

Nota: '*' Questão descartada no construto devido à polaridade.

Fonte: Elaborado pelos autores.

As variáveis independentes de controle selecionadas referem-se às características do perfil do diretor e de gestão, tais como formação, tempo no cargo na mesma escola, salário bruto e gênero. Foram incluídos ainda o ano do Saeb e a UF da escola (transformadas em variáveis binárias e inseridas simultaneamente nos modelos analisados). Neste caso, foi utilizado o Acre como base de 
comparação, pois os indicadores de clima e de liderança nas escolas deste estado situam-se próximos à média nacional.

Além disso, foram inseridos quatro indicadores de contexto do Instituto Nacional de Estudos e Pesquisas Educacionais Anísio Teixeira (Inep): nível socioeconômico médio dos alunos das escolas de educação básica ${ }^{2}$; complexidade da gestão escolar ${ }^{3}$; regularidade do corpo docente ${ }^{4}$; e adequação da formação docente ${ }^{5}$. Parte das variáveis foram agrupadas em categorias distintas dos questionários para acompanhar os achados da literatura ou porque se encaixaram melhor nos modelos. Por exemplo, o curso de pós-graduação consolidou as quatro respostas em uma variável binária, enquanto o tempo no cargo adaptou as categorias de Pereda et al. (2015).

As equações utilizadas nos modelos a serem testados são:

CLIMA_ESCOLAR $=\beta 0+\beta 1($ PROV_CARGO $)+\beta 2($ SALÁRIO $)+\beta 3($ MULHER $)+\beta 4($ POS_G $)$ $+\beta 5($ REC_FORMACAO $)+\beta 6($ ORG_FORMACAO $)+\beta 7$ (ATIV_EXTERNA $)+\beta 8($ DIF_FINANCEIRA) $+\beta 9($ ANOS_CARGO $)+\beta 10($ COMP_GESTAO $)+\beta 11($ NSE_ALUNOS $)+\beta 12($ REG_DOCENTE $)+$ $\beta 13$ (FORM_DOCENTE) $+\beta 14(\mathrm{UF})+\beta 15($ ANO $)+\mathrm{u}$

LIDERANÇA_DIRETOR $=\beta 0+\beta 1($ PROV_CARGO $)+\beta 2($ SALÁRIO $)+\beta 3($ MULHER $)+\beta 4($ POS $)+$ $\beta 5($ REC_FORMACAO $)+\beta 6($ ORG_FORMACAO $)+\beta 7($ ATIV_EXTERNA $)+\beta 8($ DIF_FINANCEIRA $)$ $+\beta 9($ ANOS_CARGO $)+\beta 10($ COMP_GESTAO $)+\beta 11($ NSE_ALUNOS $)+\beta 12($ REG_DOCENTE $)+$ $\beta 13($ FORM_DOCENTE $)+\beta 14(\mathrm{UF})+\beta 15(\mathrm{ANO})+\mathrm{u}$

O quadro completo com as variáveis utilizadas pode ser consultado na Tabela 1.

TABELA 1 ESTATÍSTICAS DESCRITIVAS DAS VARIÁVEIS UTILIZADAS NO SAEB 2013 E 2015

\begin{tabular}{l|c|c|c|c|c|c|}
\hline Variável & $\begin{array}{c}\text { No }^{\circ} \text { de } \\
\text { Escolas }\end{array}$ & Média & $\begin{array}{c}\text { Desvio } \\
\text { Padrão }\end{array}$ & Mínimo & Máximo & NA \\
\hline Clima_escolar & 38.805 & 57.3921 & 9.7386 & 23.98866 & 79.12826 & 651 \\
\hline Liderança_diretor & 38.854 & 59.1359 & 9.5945 & 14.72490 & 78.58443 & 602 \\
\hline Concurso_público_apenas & 39.098 & 0.1016 & 0.3022 & 0 & 1 & 358 \\
Eleição_apenas & 39.098 & 0.2630 & 0.4402 & 0 & 1 & 358 \\
\hline Indicação_apenas & 39.098 & 0.2355 & 0.4243 & 0 & 1 & 358
\end{tabular}

\footnotetext{
2 Definido pela renda familiar, posse de bens, contratação de serviços de empregados domésticos pela família dos alunos e nível de escolaridade de seus pais ou responsáveis.

${ }^{3}$ Calculado pelo porte (número de matrículas); número de turnos de funcionamento; complexidade das etapas ofertadas; e quantidade de etapas/modalidades oferecidas.

${ }^{4}$ Avalia a permanência do corpo docente nas escolas de educação básica nos últimos cinco anos.

${ }^{5}$ Mensura a quantidade de docentes em efetivo exercício na educação básica, cuja disciplina lecionada está alinhada à sua formação acadêmica, conforme as normativas e dispositivos legais.
} 


\begin{tabular}{|c|c|c|c|c|c|c|}
\hline Variável & $\begin{array}{l}N^{0} \text { de } \\
\text { Escolas }\end{array}$ & Média & $\begin{array}{l}\text { Desvio } \\
\text { Padrão }\end{array}$ & Mínimo & Máximo & NA \\
\hline Processo_seletivo_apenas & 39.098 & 0.0494 & 0.2168 & 0 & 1 & 358 \\
\hline Processo_seletivo_e_eleição & 39.098 & 0.2033 & 0.4024 & 0 & 1 & 358 \\
\hline Processo_seletivo_e_indicação & 39.098 & 0.0592 & 0.2360 & 0 & 1 & 358 \\
\hline Salário_bruto_diretor & 38.936 & 7.2863 & 1.9074 & 0 & 10 & 520 \\
\hline Diretor_mulher & 39.252 & 0.7479 & 0.4341 & 0 & 1 & 204 \\
\hline Pós-graduação & 38.966 & 0.8505 & 0.3564 & 0 & 1 & 490 \\
\hline Recebeu_formação_de_impacto & 39178 & 0.6815 & 0.4658 & 0 & 1 & 278 \\
\hline Organizou_formação_continuada & 38.892 & 0.7404 & 0.4384 & 0 & 1 & 564 \\
\hline Atividade_externa & 39.131 & 0.2533 & 0.4349 & 0 & 1 & 325 \\
\hline Dificuldade_financeira_escola & 39.120 & 1.1928 & 1.0798 & 0 & 3 & 336 \\
\hline De_3_a_5_anos_no_cargo & 39.165 & 0.4923 & 0.4999 & 0 & 1 & 291 \\
\hline De_6_a_10_anos_no_cargo & 39.165 & 0.1849 & 0.3882 & 0 & 1 & 291 \\
\hline De_11_a_15_anos_no_cargo & 39.165 & 0.0911 & 0.2878 & 0 & 1 & 291 \\
\hline Acima_de_15_anos_no_cargo & 39.165 & 0.0397 & 0.1954 & 0 & 1 & 291 \\
\hline Complexidade_gestão_escolar & 37.651 & 4.0144 & 1.2385 & 1 & 6 & 1.805 \\
\hline Nível_socioeconômico_alunos & 37.797 & 4.4363 & 0.9792 & 1 & 7 & 1.659 \\
\hline Regularidade_corpo_docente & 37.407 & 3.0310 & 0.5614 & 0 & 5 & 2.049 \\
\hline Adequação_formação_docente & 37.663 & 3.9500 & 10.445 & 0 & 100 & 1.823 \\
\hline UF_(27) & 39.456 & - & - & 0 & 1 & 0 \\
\hline Ano_[T.2015] & 39.456 & - & - & 0 & 1 & 0 \\
\hline
\end{tabular}

Nota: NA = respostas ausentes

Fonte: Elaborada pelos autores.

Adicionalmente, ao analisar os marcos legais sobre seleção de diretores escolares nas UFs e no Distrito Federal, constatou-se uma configuração bem heterogênea nos escopos das legislações específicas ou de gestão democrática que incluem esse tema em relação às diretrizes estabelecidas nos PEEs. Estes foram aprovados entre 2014 e 2016, exceto em Minas Gerais e no Rio de Janeiro, que ainda se encontravam em tramitação nos órgãos legislativos até dezembro de 2016. Também foi avaliada a permanência das modalidades ao longo dos anos. Em alguns casos, percebe-se um movimento de transição ao "processo seletivo e eleição", sobretudo, nos dispositivos legais mais recentes. Outros mantiveram a orientação inicial em diferentes períodos.

Os PEEs indicam a necessidade de elaboração de leis específicas para regulamentar a matéria no prazo de um ou dois anos. Desse modo, representam um passo importante para se institucionalizar uma nova política, porém não garantem sua efetivação na prática. Por esse motivo, optou-se por desconsiderar esses planos enquanto critério para classificação do método de seleção adotado em cada UF, exceto àqueles que aprovaram leis específicas posteriores. Isso facilitou a comparação com 
os microdados do Saeb nas edições de 2013 e 2015. Ressalta-se ainda que as políticas estaduais nem sempre acompanham as respostas dos diretores aos questionários, o que será observado adiante.

\section{RESULTADOS E ANÁLISES}

Nesta seção, apresentaremos os resultados das análises realizadas com base nos textos legais das UFs e do Distrito Federal, nas estatísticas descritivas baseadas nos microdados do Saeb e nos testes econométricos efetuados a partir da mesma base de dados, com o objetivo de buscar a comprovação das hipóteses anteriormente citadas.

\subsection{Análise das regras vigentes para o provimento do cargo de diretor de escola}

O critério de "eleição apenas" constitui a modalidade mais comum e foi observada em quatorze UFs e no Distrito Federal (56\%). Sua distribuição geográfica é bem abrangente, sendo quatro situadas na Região Centro-Oeste, quatro no Nordeste, três no Norte, duas no Sul e duas no Sudeste. Nota-se que sete delas parecem estar em estágio de transição da política atual para o "processo seletivo e eleição", conforme recomendação do PNE, em seu indicador 19.1. Há também uma diversidade entre os mecanismos de avaliação utilizados em cada um destes sistemas. Uma descrição detalhada de tais regras e critérios por UF pode ser encontrada no Apêndice.

Atualmente, somente São Paulo regulamenta o "concurso público apenas", enquanto o "processo seletivo apenas" foi localizado somente no Amazonas. Roraima foi o único classificado como "indicação apenas", devido à ausência de marcos legais sobre a matéria anteriores ao PEE6. Aponta-se ainda, em contrapartida, a alta incidência desta modalidade em muitos estados na análise dos microdados, mesmo em divergência com as legislações.

Além disso, conforme parecer do Supremo Tribunal Federal (STF) ${ }^{7}$, é considerada competência privativa do Chefe do Poder Executivo o provimento de cargos em comissão para diretores de escola pública, que deverá ser objeto de livre nomeação pelo governo local. O órgão atribui inconstitucionalidade a toda normativa que preveja eleições diretas, com participação da comunidade, para direção de escolas mantidas pelo Poder Público. Embora seja mencionada em dispositivos legais de governos subnacionais no Brasil e no Saeb, não configura um processo eleitoral padrão, pois não assegura a permanência dos diretores nos cargos durante todo o mandato. Por este motivo, utiliza-se o termo consulta pública à comunidade escolar no PNE.

O "processo seletivo e eleição", por sua vez, abrange nove UFs (33\%) e constitui a segunda modalidade mais popular no país. Sua distribuição geográfica é predominante na Região Nordeste, com cinco ocorrências, seguida por duas no Norte, uma no Sul e uma no Sudeste. Excluíram-se desta categoria as sete UFs cujos PEEs indicam um movimento de mudança para o método misto, porém ainda não consolidado por outros dispositivos legais.

$\mathrm{Na}$ análise das legislações e normativas, não foi possível identificar nenhuma UF que estabeleceu os critérios de "processo seletivo e indicação" ou a modalidade "outra forma”. Ainda assim, houve um

\footnotetext{
${ }^{6}$ Este plano prevê a adoção de critérios técnicos de mérito e de desempenho, mas foi desconsiderado pelos motivos já esclarecidos. Durante a pesquisa documental, não se identificaram leis ou normas específicas com tal regulamentação, apenas um movimento da sociedade civil favorável à "eleição apenas" em detrimento à "indicação apenas". Logo, deduziu-se que este método prevaleceu como política até 2016, o que foi confirmado pelos microdados, conforme análise na próxima seção.

${ }^{7}$ Ação Direta de Inconstitucionalidade (ADI) n 2997, de 12 de agosto de 2009.
} 
percentual expressivo de respostas dos diretores nestas categorias quando analisados os microdados, o que ocorrerá na próxima seção.

\subsection{Análise descritiva das formas de provimento ao cargo de diretor escolar por UF a partir dos microdados do Saeb}

Após analisar a legislação, procedeu-se à análise das estatísticas descritivas sobre o provimento do cargo de diretor, baseadas nas respostas dos diretores aos questionários do Saeb de 2013 e de 2015. A "eleição apenas" novamente foi a modalidade mais popular entre as escolas, seguida por "indicação apenas" e pelo "processo seletivo e eleição". Em contrapartida, o "processo seletivo apenas" teve a menor incidência entre as UFs, seguido pelo "processo seletivo e indicação".

Os percentuais de distribuição por modalidade são observados no Gráfico 1.

\section{GRÁFICO 1 PROVIMENTO AO CARGO DE DIRETOR POR MODALIDADE NO SAEB 2013 E 2015}

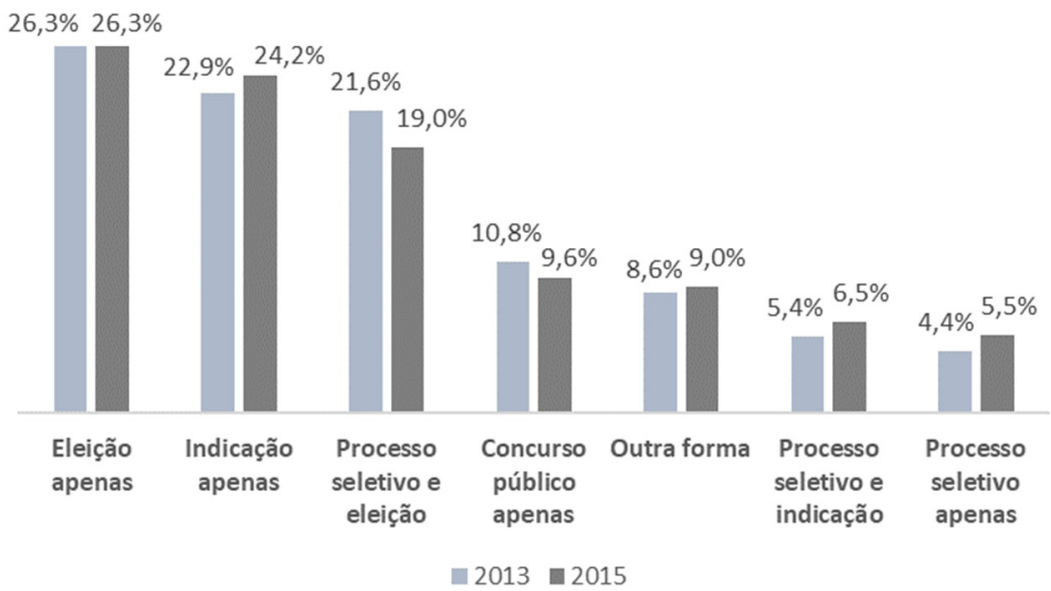

Fonte: Elaborado pelos autores.

Sob a ótica do território, nota-se uma grande heterogeneidade em relação à distribuição das modalidades ${ }^{8}$. O "concurso público apenas" concentra-se em São Paulo. O "processo seletivo apenas" é mais comum no Espírito Santo e no Rio de Janeiro (2015). A “eleição apenas" prevalece no Distrito Federal e em sete UFs: Alagoas, Mato Grosso, Paraná, Piauí (2013), Rio Grande do Norte, Rio Grande do Sul e Rondônia. Já a “indicação apenas” predomina em onze UFs: Amapá, Amazonas, Maranhão, Pará, Paraíba, Piauí (2015), Rio de Janeiro (2013), Roraima, Santa Catarina, Sergipe e Tocantins.

No Gráfico 2 mostra a distribuição destes percentuais por UF entre as modalidades únicas de seleção. Observa-se que há uma maior dispersão nas modalidades de "eleição apenas" e "indicação apenas", ou seja, onde estão concentradas a maioria das UFs. Por outro lado, a dispersão é baixa quando

${ }^{8}$ Rio de Janeiro e Piauí foram contados duas vezes, pois suas modalidades de seleção mais comuns se alternaram em 2013 e 2015. 
analisado o "concurso público apenas" e o "processo seletivo apenas", onde todas as UFs estão abaixo de $50 \%$ e a grande maioria são inferiores a $10 \%$.

\section{GRÁFICO 2 PROVIMENTO AO CARGO DE DIRETOR POR MODALIDADE ÚNICA NO SAEB 2013 E 2015}

\begin{tabular}{|c|c|c|c|c|c|c|c|c|}
\hline & & Concurso & & Eleição & & Indicação & & Processo Seletivo \\
\hline 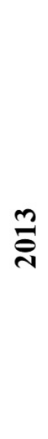 & \begin{tabular}{r|r}
$90 \%$ \\
$80 \%$ \\
$70 \%$ \\
$60 \%$ \\
$50 \%$ \\
$40 \%$ \\
$30 \%$ \\
$20 \%$ \\
$10 \%$ \\
$0 \%$
\end{tabular} & 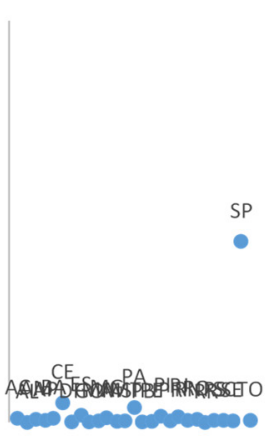 & $\begin{array}{r}100 \% \\
90 \% \\
80 \% \\
70 \% \\
60 \% \\
50 \% \\
40 \% \\
30 \% \\
20 \% \\
10 \% \\
0 \%\end{array}$ & 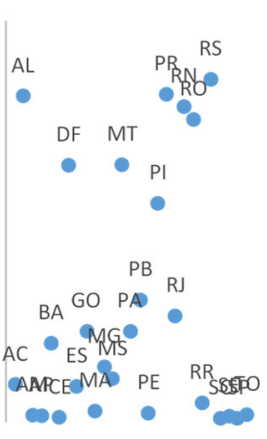 & $\begin{array}{r}100 \% \\
90 \% \\
80 \% \\
70 \% \\
60 \% \\
50 \% \\
40 \% \\
30 \% \\
20 \% \\
10 \% \\
0 \%\end{array}$ & 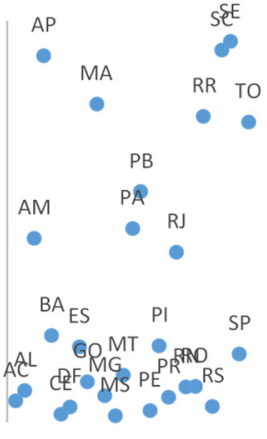 & $\begin{array}{r}100 \% \\
90 \% \\
80 \% \\
70 \% \\
60 \% \\
50 \% \\
40 \% \\
30 \% \\
20 \% \\
10 \% \\
0 \%\end{array}$ & 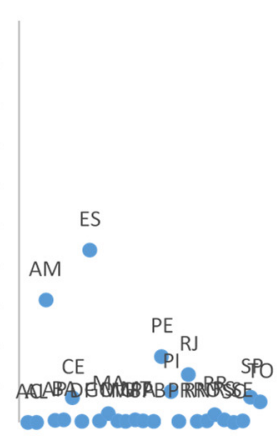 \\
\hline 年 & $\begin{array}{r}100 \% \\
90 \% \\
80 \% \\
70 \% \\
60 \%\end{array}$ & 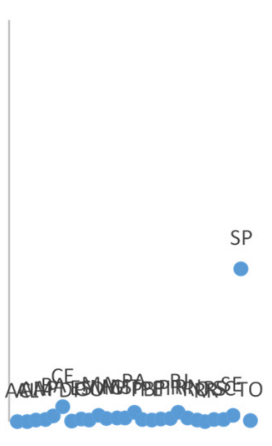 & $\begin{array}{r}100 \% \\
90 \% \\
80 \% \\
70 \% \\
60 \%\end{array}$ & 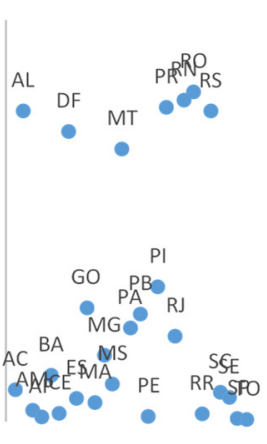 & $\begin{array}{r}100 \% \\
90 \% \\
80 \% \\
70 \% \\
60 \% \\
50 \% \\
40 \% \\
30 \% \\
20 \% \\
10 \% \\
0 \%\end{array}$ & 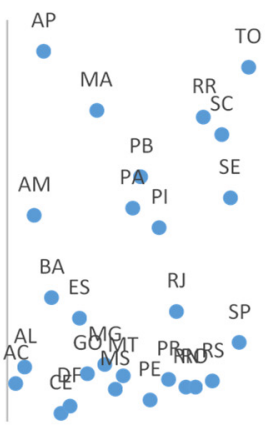 & $\begin{array}{r}100 \% \\
90 \% \\
80 \% \\
70 \% \\
60 \% \\
50 \% \\
40 \% \\
30 \% \\
20 \%\end{array}$ & 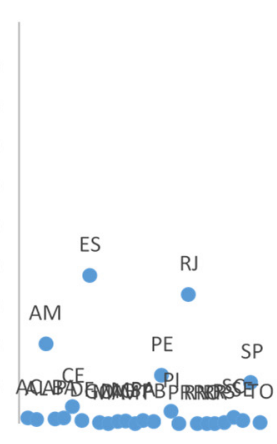 \\
\hline
\end{tabular}

Fonte: Elaborado pelos autores.

Entre as modalidades mistas, destaca-se somente o "processo seletivo e eleição", em que a dispersão é alta e há maior concentração em sete UFs: Acre, Bahia, Ceará, Goiás, Mato Grosso do Sul, Minas Gerais e Pernambuco. Já o "processo seletivo e indicação" e a "outra forma" não prevalecem em nenhum estado, o que pode ser observado devido à baixa dispersão destas modalidades.

O Gráfico 3 mostra a mesma distribuição percentual por UF entre as modalidades mistas de seleção. 


\section{GRÁFICO 3 PROVIMENTO AO CARGO DE DIRETOR POR MODALIDADE MISTA NO SAEB 2013 E 2015}

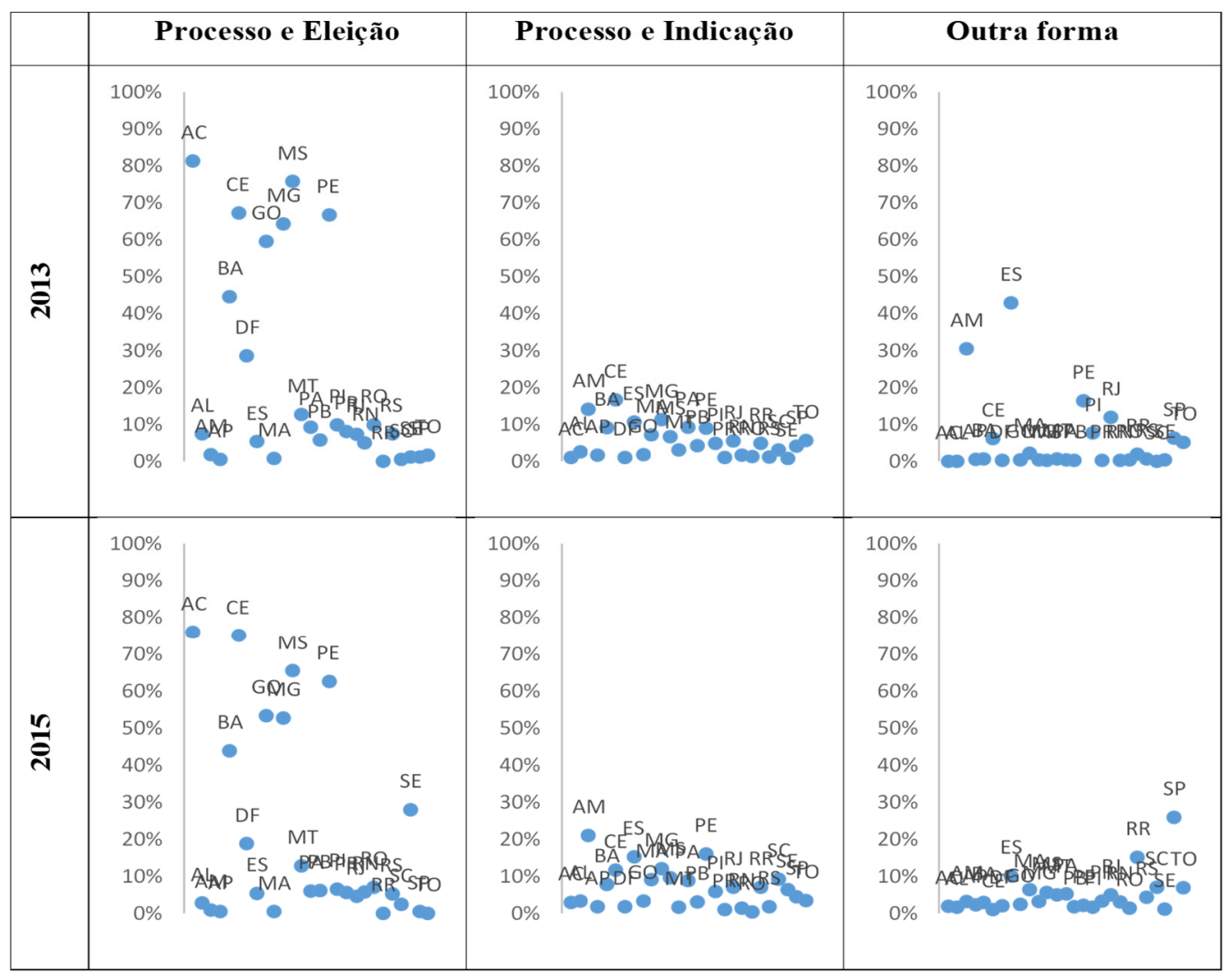

Fonte: Elaborado pelos autores.

\subsection{Testes referentes ao Modelo 1: Efeitos da forma de provimento ao cargo sobre 0 clima escolar}

Posteriormente à análise legal e empírica das formas de provimento, foram realizados os testes econométricos que possibilitaram avaliar se o método de escolha dos diretores de escola influencia na percepção sobre o clima escolar, com base no construto adaptado a partir de Oliveira e Waldhelm (2016) e nas equações descritas na seção metodológica. Antes de proceder aos testes, foi analisada a consistência interna do questionário aplicado para o clima escolar.

A confiabilidade de consistência interna deste construto foi estimada pelo coeficiente Alfa de Cronbach, calculado a partir da variância dos itens individuais e das covariâncias entre eles. No indicador de clima escolar, os quatro itens estão na faixa entre 0,77 a 0,81 e, juntos, de 0,83 . Isso evidencia sua confiabilidade, pois se considera satisfatório o valor de $\alpha \geq 0,70$. Na matriz de correlação policórica, os valores são positivos e têm coeficiente superior a 0,45 , um indício de que todos esses itens podem estar associados a um único construto. Já os autovalores apontam 2,61 no primeiro item, quase cinco vezes superior ao segundo $(0,56)$, sendo que o terceiro e o quarto são ainda menores. Portanto, considera-se a suposição de unidimensionalidade válida.

O Gráfico 4 apresenta a distribuição dos valores médios do indicador de clima escolar por escola, com amplitude de 23,99 até 79,13. Ressalta-se que os parâmetros do indicador foram ajustados para 
a média de 50, com desvio padrão de 10. Dentre 39.456 observações, 7.565 foram descartadas por não apresentarem nenhuma resposta nas variáveis utilizadas.

\section{GRÁFICO 4 DISTRIBUIÇÃO DOS VALORES MÉDIOS DO INDICADOR DE CLIMA ESCOLAR POR ESCOLA}

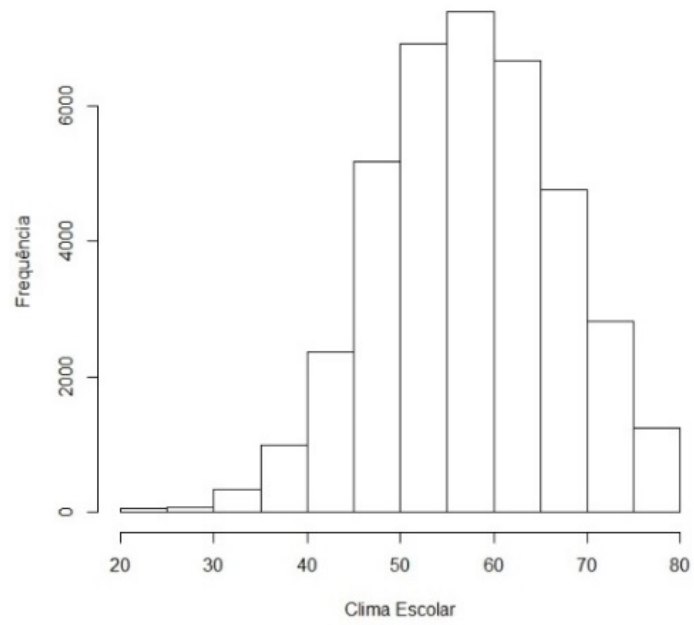

Fonte: Elaborado pelos autores.

A estimação dos resultados das equações descritas na seção metodológica, através da aplicação do método de regressão linear múltipla, identificou que a variável de seleção dos diretores foi estatisticamente significante para explicar o comportamento da variável clima escolar médio. Isso porque o p-valor do teste de hipótese, relacionado ao coeficiente da modalidade de seleção, foi estimado em menos do que 2.2e-16. A interpretação desse resultado indica a rejeição da hipótese nula (H0: Beta $=0$ ), concluindo-se que o coeficiente ajustado para a modalidade de seleção é estatisticamente diferente de zero.

O "concurso público apenas" obteve a maior elasticidade ceteris paribus sobre o clima escolar médio, com coeficiente de 1,36, indicando haver maior colaboração entre o corpo docente nas atividades pedagógicas cotidianas. Em seguida, vem o "processo seletivo e eleição" $(0,80)$. Ambas foram estatisticamente significantes ao nível de significância de $0,1 \%$. As modalidades únicas de "processo seletivo apenas" $(0,59)$, de "eleição apenas" $(0,48)$ e de "indicação apenas" $(0,43)$ apresentaram nível de significância a 5\%. Ressalta-se que a variável referente ao "processo seletivo e indicação" foi utilizada como base de comparação. Os efeitos podem ser observados na Tabela 2, da seção de análise conjunta dos resultados para as variáveis liderança e clima escolar.

Ainda que a modalidade de seleção contribua para explicar a variação no clima escolar médio, é necessário considerar outras variáveis explicativas incluídas no modelo e que se apresentaram relevantes. Em relação ao perfil do diretor e de gestão, destacam-se o tempo entre 11 a 15 anos no cargo na mesma escola $(0,72)$, a organização de formações $(0,98)$, o gênero feminino $(0,91)$ e a pós-graduação $(0,57)$, com efeito positivo. No outro sentido, citam-se os diretores que exercem atividades externas $(-0,43)$. Entre os indicadores de contexto escolar do Inep, a complexidade da gestão escolar mostrou 
a maior relevância estatística $(-1,37)$. Logo, quanto maior o porte, quantidade de turmas e etapas oferecidas, menor é o clima escolar médio. Já a regularidade docente, que mensura a permanência dos professores nas escolas nos últimos cinco anos, possui efeito positivo $(1,19)$.

De modo geral, a variável relativa às UFs teve a maior alteração entre os efeitos neste modelo, pois agrega outros fatores não observáveis ou não explicitados e que exercem o papel de controle para isolar o efeito da modalidade de seleção sobre o clima escolar. Isso corrobora o argumento de Urick e Bowers (2014), visto que a atuação gerencial do diretor e o clima são influenciados pelo contexto escolar. Assim, as características institucionais de cada Secretaria de Educação devem estar sendo parcialmente captadas neste indicador, apontando a necessidade de uma análise futura sobre a capacidade estatal dos órgãos e os processos de controle e de acompanhamento pedagógico junto às escolas, entre outros fatores de ordem política e econômica.

Os menores valores foram observados nos estados do Pará, Santa Catarina e Sergipe, com coeficientes acima de 9 e polaridade negativa. Embora o Pará tenha sido classificado como "eleição apenas" na análise dos marcos legais e, os demais, como "processo seletivo e eleição", a análise dos microdados aponta a prevalência da "indicação apenas". Na faixa entre -6,2 a -7,2 encontram-se Alagoas, Paraná, Piauí e Rio Grande do Norte, que foram categorizados como "eleição apenas" (em transição para o "processo seletivo e eleição"), em convergência com o que observamos na análise dos microdados. Logo abaixo, estão o Maranhão e o Rio de Janeiro $(-5,86)$. O primeiro regulamentou o "processo seletivo e eleição", mas predomina a "indicação apenas". O segundo consolidou a "eleição apenas" em legislação específica de 2016. Porém, a análise dos microdados sugere uma tendência de substituição da "indicação apenas" pelo "processo seletivo apenas".

As UFs que obtiveram os maiores coeficientes positivos são: Espírito Santo, Minas Gerais e São Paulo, além do Distrito Federal, na faixa entre 2,96 e 3,71. Em nenhum caso prevalece a "indicação apenas". Neste último, há maior concentração de "eleição apenas" quando observados os microdados, em convergência com a legislação. Em São Paulo há convergência com o "concurso público apenas", além do maior percentual de respostas "outra forma” (26\%). O Espírito Santo possui uma das regulamentações mais antigas sobre o "processo seletivo e eleição", porém os diretores apontam maior concentração do "processo seletivo apenas". Já Minas Gerais foi classificado como "eleição apenas", embora a análise dos microdados indica a predominância do "processo seletivo e eleição". Ceará, Bahia e Tocantins, por sua vez, também apresentaram valores positivos, todavia, com relevância estatística somente ao nível de significância a $10 \%$.

Conclui-se, de modo geral, que as maiores médias para o indicador de clima escolar foram encontradas nas escolas onde ocorreu o "concurso público apenas", seguidas pelo "processo seletivo e eleição", segundo as respostas nos questionários. Em contrapartida, a "indicação apenas" teve o menor efeito, próximo às modalidades de "eleição apenas" e de "processo seletivo apenas". Quando analisados por UFs, os coeficientes mais altos foram vistos na capital federal e em três estados da Região Sudeste, onde prevalecem critérios técnicos e/ou participativos tanto nas leis como nos microdados. Já a “indicação apenas" predomina nas três UFs com os menores coeficientes, embora suas leis indiquem outras modalidades. Entre os demais fatores, destacam-se àqueles associados ao contexto da escola: complexidade da gestão escolar (com efeito negativo) e regularidade do corpo docente (com efeito positivo). 


\subsection{Testes referentes ao Modelo 2: Efeitos da forma de provimento ao cargo de diretor sobre a liderança do diretor}

Nesta seção apresentamos os resultados dos testes econométricos que possibilitaram avaliar se o método de escolha dos diretores de escola influencia na percepção sobre a liderança do diretor, também com base com base na adaptação do construto de Oliveira e Waldhelm (2016) e nas equações descritas na seção metodológica. Novamente, antes de proceder aos testes, foi analisada a consistência interna do questionário aplicado para a liderança do diretor.

O Alfa de Cronbach do construto de liderança do diretor teve coeficiente de 0,947 para todos os itens juntos, sendo o menor deles 0,938 , apontando forte consistência interna do questionário e a confiabilidade do modelo $(\alpha \geq 0,70)$. Já a matriz de correlação policórica apresentou valores positivos dos itens na faixa de 0,48 a 0,87 , indicando que podem estar associados a um único construto. $\mathrm{Na}$ análise dos autovalores e dos autovetores, o primeiro teve coeficiente de 6,95 , bem superior aos demais, abaixo de 0,8 . Portanto, considera-se a suposição de unidimensionalidade válida.

O Gráfico 5 demonstra a distribuição dos valores médios do indicador de liderança do diretor por escola, com amplitude de 14,72 até 78,58 . Os parâmetros foram ajustados para a média 50 , com desvio padrão 10. Dentre 39.456 observações, 7.540 foram descartadas por não apresentarem nenhuma resposta nas variáveis utilizadas.

\section{GRÁFICO 5 DISTRIBUIÇÃO DOS VALORES MÉDIOS DO INDICADOR DE LIDERANÇA DO DIRETOR POR ESCOLA}

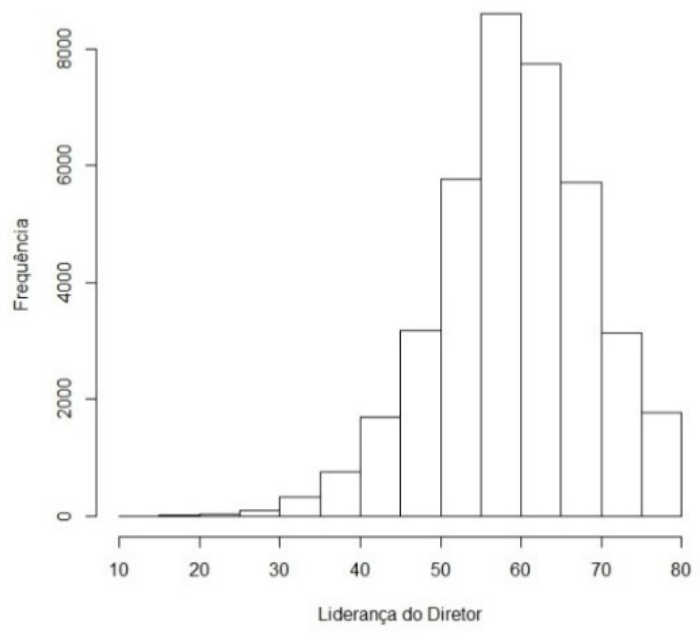

Fonte: Elaborado pelos autores.

Assim como no modelo anterior, na aplicação do método de regressão linear múltipla, identificou-se que a variável de seleção dos diretores foi estatisticamente significante para explicar o comportamento da variável liderança média do diretor. Isso pode ser afirmado porque o p-valor do teste de hipótese, relacionado ao coeficiente da forma de seleção, foi estimado em menos que 2.2e-16. A interpretação 
desse resultado indica a rejeição da hipótese nula $(\mathrm{H} 0$ : Beta $=0)$, visto que o coeficiente ajustado para a modalidade de seleção é estatisticamente diferente de zero.

Neste modelo, o "concurso público apenas" também teve a maior elasticidade ceteris paribus em relação à liderança média do diretor $(1,65)$, a um nível de significância de $0,1 \%$. O "processo de seleção e eleição" $(0,77)$ apresentou coeficiente próximo à eleição apenas $(0,74)$, ambos com nível de significância a 1\%. As modalidades de "indicação apenas" e de "processo seletivo apenas", entretanto, não se comprovaram estatisticamente significantes. Da mesma forma, a variável referente ao "processo seletivo e indicação" foi utilizada como base para comparação. Os efeitos podem ser observados na Tabela 2, da seção de análise conjunta dos resultados para as variáveis liderança e clima escolar.

Entre as demais variáveis explicativas associadas ao perfil do diretor e de gestão, incluídas no modelo testado e previamente apresentado na seção metodológica, destacam-se a organização de formações para os docentes $(1,35)$, a pós-graduação $(1,32)$, o gênero feminino $(1,19)$, o tempo no cargo na mesma escola entre 11 e 15 anos $(1,11)$ e os diretores capacitados nos últimos 2 anos $(0,81)$. Com menor contribuição ao acréscimo da liderança e polaridade negativa, citam-se as atividades externas $(-0,46)$ e a dificuldade financeira da escola $(-0,21)$. Entre os indicadores de contexto do Inep, a complexidade da gestão escolar $(-0,86)$ e a regularidade docente $(0,78)$ tiveram maior relevância, seguidos pelo nível socioeconômico médio dos alunos $(-0,31)$.

Novamente, as variáveis de controle das UFs indicam contribuir com o maior aumento ou maior redução na média do indicador de liderança escolar, com destaque para Goiás $(3,50)$ e Pernambuco $(3,04)$. Em ambos predomina, segundo a análise descritiva baseada nos microdados, o "processo seletivo e eleição". Há convergência desta modalidade mista com os marcos legais em Pernambuco, enquanto Goiás foi classificado como "eleição apenas". Os estados do Amazonas, Minas Gerais, Paraíba e Rio de Janeiro também apresentaram coeficientes significativos, na faixa de 2,19 a 2,45. No primeiro, o "processo seletivo apenas" é regulamentado por lei, contudo, houve maior concentração da "indicação apenas". O mesmo ocorre na Paraíba e no Rio de Janeiro (2013), onde prevalece a "indicação apenas" em detrimento aos marcos legais sobre "eleição apenas". Em Minas Gerais, a incidência é maior do "processo seletivo e eleição", embora suas leis apontem "eleição apenas".

Com polaridade negativa e alto impacto na percepção média de liderança do diretor, citam-se Pará $(-5,86)$, Sergipe $(-5,09)$, Amapá $(-3,19)$ e Roraima $(-3,18)$. Em todos houve maior incidência da "indicação apenas" segundo a análise dos microdados, entretanto, com diferentes categorias normativas: "eleição apenas" no Pará e no Amapá; "processo seletivo e eleição" no Sergipe; e "indicação apenas" em Roraima. Ligeiramente abaixo está o Rio Grande do Norte $(-2,89)$, com sinergia entre a legislação e os microdados analisados quanto à "eleição apenas", mas em aparente transição para o "processo seletivo e eleição".

Conclui-se, de modo geral, que os maiores valores médios do indicador de liderança do diretor ocorrem nas unidades de ensino onde houve "concurso público apenas" para provimento a este cargo, seguidas pelo "processo seletivo e eleição" e "eleição apenas" (com efeito reduzido), considerando as respostas nos questionários. Em contrapartida, a "indicação apenas" e o "processo seletivo apenas" não se mostraram estatisticamente significantes neste modelo. Sob a ótica territorial, as duas UFs com os maiores valores médios de liderança tiveram maiores percentuais de "processo seletivo e eleição", sendo uma em convergência com a legislação e outra classificada como "eleição apenas". Por outro lado, a "indicação apenas" é mais comum nas quatro UFs com os menores valores médios, apesar de suas legislações regulamentarem outros critérios. Destacaram-se ainda os fatores associados ao perfil 
do diretor e de gestão: pós-graduação, gênero feminino, permanência no cargo na mesma escola entre 11 e 15 anos e os diretores que organizaram ou receberam formações nos últimos dois anos.

\subsection{Análise conjunta dos resultados para as variáveis liderança e clima escolar}

Portanto, há semelhanças significativas entre os resultados obtidos nos dois modelos. As modalidades com critérios técnicos (concurso público apenas) ou com participação da comunidade escolar (processo seletivo e eleição) registraram as médias mais expressivas nos coeficientes de clima escolar e de liderança do diretor, em detrimento dos resultados para o provimento por "indicação apenas". Porém, a variação entre os coeficientes de clima e liderança nas UFs e no Distrito Federal foram ainda superiores, evidenciando que as características regionais são determinantes importantes sobre a percepção do corpo docente. Por fim, sugere-se que os fatores ligados ao contexto escolar (Inep) exercem maior efeito sobre o clima escolar médio, enquanto àqueles fatores relacionados ao perfil do diretor e de gestão (ex.: pós-graduação, tempo no cargo na mesma escola) estão mais associados à percepção média de liderança.

A Tabela 2 contém os escores obtidos nos dois modelos analisados.

\section{TABELA 2 REGRESSÃO LINEAR MÚLTIPLA PARA LIDERANÇA DO DIRETOR E CLIMA ESCOLAR}

\begin{tabular}{|c|c|c|c|c|}
\hline VD & LIDERANÇ & SETOR & CLIMA & LAR \\
\hline Variáveis Independentes & Estimativa & Std. Error & Estimativa & Std. Error \\
\hline (Intercepto) & $55.687315^{\star \star \star}$ & (0.799605) & $56.306334^{\star \star \star}$ & $(0.717069)$ \\
\hline Concurso_público_apenas & $1.646511^{\star \star \star}$ & (0.298004) & $1.360552^{\star \star \star}$ & $(0.267461)$ \\
\hline Eleição_apenas & $0.738387^{\star \star}$ & $(0.253610)$ & $0.476487^{*}$ & (0.227682) \\
\hline Indicação_apenas & 0.227849 & $(0.238804)$ & $0.426758^{*}$ & $(0.214452)$ \\
\hline Processo_seletivo_apenas & 0.462445 & $(0.314750)$ & $0.593090^{*}$ & $(0.282365)$ \\
\hline Processo_seletivo_e_eleicao & $0.772306^{\star \star}$ & $(0.243553)$ & $0.795453^{\star \star \star}$ & $(0.218507)$ \\
\hline De_3_a_5_anos_no_cargo & -0.140970 & $(0.131714)$ & -0.055220 & $(0.118149)$ \\
\hline De_6_a_10_anos_no_cargo & 0.178734 & $(0.152210)$ & 0.217331 & $(0.136530)$ \\
\hline De_11_a_15_anos_no_cargo & $1.108839^{\star \star \star}$ & (0.196165) & $0.718451^{\star \star \star}$ & $(0.175911)$ \\
\hline Acima_de_15_anos_no_cargo & 0.428728 & (0.275392) & 0.323784 & $(0.246927)$ \\
\hline Gênero_feminino & $1.185838^{\star \star \star}$ & $(0.122417)$ & $0.911323^{\star \star \star}$ & $(0.109805)$ \\
\hline Pos_graduacao & $1.320912^{\star \star \star}$ & $(0.154930)$ & $0.568827^{\star \star \star}$ & $(0.138998)$ \\
\hline Salário_bruto_diretor & $0.206206^{\star \star \star}$ & $(0.036652)$ & $0.137138^{\star \star \star}$ & $(0.032857)$ \\
\hline Atividade_externa & $-0.457719^{\star \star \star}$ & (0.127994) & $-0.427450^{\star * *}$ & $(0.114842)$ \\
\hline Recebeu_formação_de_impacto & $0.806481^{\star \star \star}$ & $(0.114163)$ & $0.203486^{*}$ & $(0.102401)$ \\
\hline Organizou_formação_continuada & $1.345734^{\star \star \star}$ & (0.128323) & $0.977657^{\star \star \star}$ & $(0.115103)$ \\
\hline Dificuldade_financeira_escola & $-0.205385^{\star \star \star}$ & $(0.050728)$ & $-0.090582^{\star}$ & $(0.045502)$ \\
\hline Nível_socioeconômico_alunos & $-0.309474^{\star \star \star}$ & $(0.070324)$ & 0.072454 & $(0.063094)$ \\
\hline Complexidade_gestao_escolar & $-0.862131^{\star \star \star}$ & $(0.044738)$ & $-1.368843^{\star \star *}$ & $(0.040102)$ \\
\hline
\end{tabular}




\begin{tabular}{|c|c|c|c|c|}
\hline \multirow{2}{*}{$\begin{array}{l}\text { VD } \\
\text { Regularidade_corpo_docente }\end{array}$} & \multicolumn{2}{|c|}{ LIDERANÇA DIRETOR } & \multicolumn{2}{|c|}{ CLIMA ESCOLAR } \\
\hline & $0.782851^{\star * \star}$ & $(0.115911)$ & $1.189774^{\star \star \star}$ & $(0.104019)$ \\
\hline Adequação_formação_docente & -0.009864 & (0.005483) & $0.018936^{\star \star \star}$ & $(0.004925)$ \\
\hline RO & $-1.789910^{\star \star}$ & $(0.693807)$ & $-4.476555^{\star \star \star}$ & (0.621773) \\
\hline AM & $2.448696^{\star \star \star}$ & $(0.644756)$ & $-1.666005^{\star \star}$ & $(0.579317)$ \\
\hline $\mathrm{RR}$ & $-3.183769^{\star \star \star}$ & $(0.952001)$ & $-4.847660^{\star \star \star}$ & $(0.853545)$ \\
\hline PA & $-5.862145^{\star \star \star}$ & $(0.642764)$ & $-10.626578^{* * *}$ & $(0.577213)$ \\
\hline AP & $-3.189508^{\star \star \star}$ & $(0.798474)$ & $-3.401664^{\star \star \star}$ & $(0.715227)$ \\
\hline TO & 1.139944 & $(0.682579)$ & 1.035055 & $(0.614960)$ \\
\hline MA & $-1.816243^{\star}$ & $(0.797837)$ & $-5.859191^{* * *}$ & $(0.713269)$ \\
\hline PI & $-1.778065^{\star}$ & $(0.695840)$ & $-6.750230^{\star \star \star}$ & $(0.623865)$ \\
\hline CE & $1.615394^{\star}$ & $(0.759876)$ & 1.150122. & $(0.686450)$ \\
\hline RN & $-2.885094^{\star \star \star}$ & $(0.659799)$ & $-6.555051^{\star \star \star}$ & $(0.591575)$ \\
\hline PB & $2.193275^{\star \star}$ & $(0.690064)$ & -0.389019 & (0.621202) \\
\hline PE & $3.041047^{\star \star \star}$ & $(0.607218)$ & -2.078997 & $(0.544403)$ \\
\hline $\mathrm{AL}$ & -0.948738 & $(0.756474)$ & $-7.219218^{\star \star \star}$ & $(0.678236)$ \\
\hline SE & $-5.093671^{\star \star \star}$ & $(0.696007)$ & $-9.263094^{\star \star \star}$ & $(0.623206)$ \\
\hline BA & -0.341517 & $(0.611446)$ & 1.057532 & (0.547973) \\
\hline MG & $2.432379^{\star \star \star}$ & (0.549039) & $2.960575^{\star \star \star}$ & (0.492232) \\
\hline ES & 1.316954 & (0.702545) & $3.663726^{\star \star \star}$ & (0.629661) \\
\hline RJ & $2.428588^{\star \star \star}$ & $(0.609854)$ & $-5.868012^{\star \star \star}$ & $(0.546665)$ \\
\hline SP & -0.156459 & $(0.576711)$ & $3.575618^{\star \star \star}$ & $(0.517080)$ \\
\hline PR & $1.457083^{*}$ & $(0.573466)$ & $-6.250644^{\star \star *}$ & $(0.514111)$ \\
\hline SC & -0.965873 & (0.606219) & $-9.029309^{\star \star \star}$ & $(0.543571)$ \\
\hline RS & $1.893707^{\star \star}$ & (0.601664) & $-1.679507^{\star \star}$ & $(0.539444)$ \\
\hline MT & $-1.379145^{\star}$ & (0.628782) & -0.120073 & $(0.563676)$ \\
\hline MS & 1.080223 & (0.665212) & $-3.780827^{\star \star \star}$ & (0.596646) \\
\hline GO & $3.499895^{\star \star \star}$ & (0.582215) & $-2.240160^{\star \star \star}$ & (0.521973) \\
\hline DF & $-1.629740^{\star \star}$ & $(0.631616)$ & $3.706162^{\star \star \star}$ & (0.566323) \\
\hline Ano_[T.2015] & 0.013826 & $(0.107426)$ & 0.029994 & $(0.096361)$ \\
\hline
\end{tabular}

Nota: Escala de códigos de significância ${ }^{(* * *)}(0,001) ;{ }^{(* *)}(0,01)$; $^{(*)}(0,05) ; . .(0,1) ;$ " (1).

Fonte: Elaborada pelos autores.

O Quadro 2, por sua vez, consolida os resultados de análise dos marcos legais e dos microdados do Saeb para cada ente federado. A classificação qualitativa adotada para os coeficientes de regressão linear visa facilitar a comparabilidade entre escalas e uma visão sistêmica sobre os aspectos de formulação (legislação) e de implementação (microdados) das políticas de seleção de diretores. Sua finalidade é específica para uso nestes modelos e não deve ser replicada aleatoriamente. O julgamento substantivo de pontos de corte por especialistas deve refletir ganhos de qualidade em escolas segundo atributos mensurados pelas variáveis analisadas e suas respectivas categorias (UNESCO, 2019). 


\section{QUADRO 2 MARCOS LEGAIS E MICRODADOS SAEB POR CLIMA ESCOLAR E LIDERANÇA DO DIRETOR}

\begin{tabular}{|c|c|c|c|c|c|c|}
\hline $\begin{array}{l}\text { Leis Estaduais } \\
\text { (Classificação) }\end{array}$ & UF & $\begin{array}{l}\text { Microdados do SAEB } \\
\text { (Predominância) }\end{array}$ & $\begin{array}{l}\text { Liderança Diretor } \\
\text { (Coeficiente) }\end{array}$ & & $\begin{array}{l}\text { Clima Escole } \\
\text { (Coeficiente }\end{array}$ & \\
\hline \multirow{8}{*}{$\begin{array}{l}\text { Eleição Apenas } \\
\text { (consolidada) }\end{array}$} & AP & Indicação & Médio baixo & $y$ & Médio baixo & $y$ \\
\hline & PA & Indicação & Baixo & $\downarrow$ & Muito baixo & $\downarrow$ \\
\hline & PB & Indicação & Médio alto & त & Sem efeito & $\Rightarrow$ \\
\hline & G0 & Processo com Eleição & Médio alto & $\pi$ & Médio baixo & $y$ \\
\hline & MT & Eleição & Médio baixo & y & Sem efeito & $\Rightarrow$ \\
\hline & $M G$ & Processo com Eleição & Médio alto & $\pi$ & Médio alto & $\eta$ \\
\hline & RJ & Indicação » Processo & Médio alto & $\pi$ & Baixo & $\downarrow$ \\
\hline & RS & Eleição & Médio alto & $\pi$ & Médio baixo & $y$ \\
\hline \multirow{7}{*}{$\begin{array}{l}\text { Eleições Apenas } \\
\text { (Transição) }\end{array}$} & RO & Eleição & Médio baixo & y & Médio baixo & $y$ \\
\hline & $\mathrm{AL}$ & Eleição & Sem efeito & $\Rightarrow$ & Baixo & $\downarrow$ \\
\hline & $\mathrm{Pl}$ & Eleição » Indicação & Médio baixo & y & Baixo & $\downarrow$ \\
\hline & RN & Eleição & Médio baixo & y & Baixo & $\downarrow$ \\
\hline & DF & Eleição & Médio baixo & $y$ & Médio alto & $\pi$ \\
\hline & MS & Processo com Eleição & Sem efeito & $\Rightarrow$ & Médio baixo & y \\
\hline & PR & Eleição & Médio alto & $\pi$ & Baixo & $\downarrow$ \\
\hline \multirow{4}{*}{$\begin{array}{l}\text { Processo e Eleição } \\
\text { (Transição) }\end{array}$} & $A C$ & Processo com Eleição & Sem efeito & $\Rightarrow$ & Sem efeito & $\Rightarrow$ \\
\hline & TO & Indicação & Sem efeito & $\Rightarrow$ & Sem efeito & $\Rightarrow$ \\
\hline & BA & Processo com Eleição & Sem efeito & $\Rightarrow$ & Sem efeito & $\Rightarrow$ \\
\hline & MA & Indicação & Médio baixo & y & Baixo & $\downarrow$ \\
\hline \multirow{5}{*}{$\begin{array}{l}\text { Processo e Eleição } \\
\text { (Consolidada) }\end{array}$} & CE & Processo com Eleição & Médio alto & $\pi$ & Sem efeito & $\Rightarrow$ \\
\hline & PE & Processo com Eleição & Médio alto & $\pi$ & Sem efeito & $\Rightarrow$ \\
\hline & SE & Indicação & Baixo & $\downarrow$ & Baixo & $\downarrow$ \\
\hline & SC & Indicação & Sem efeito & $\Rightarrow$ & Baixo & $\downarrow$ \\
\hline & ES & Processo Seletivo & Sem efeito & $\Rightarrow$ & Médio alto & $\pi$ \\
\hline Processo Sel. Apenas & AM & Indicação & Médio alto & $\pi$ & Médio baixo & $y$ \\
\hline Concurso Pub. Apenas & $\mathrm{SP}$ & Concurso & Sem efeito & $\Rightarrow$ & Médio alto & 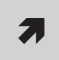 \\
\hline Indicação Apenas & $\mathrm{RR}$ & Indicação & Médio baixo & y & Médio baixo & y \\
\hline
\end{tabular}

Escala: Muito baixo (abaixo de $1 \sigma$ negativo) / Baixo (de 0,5 até $1 \sigma$ negativo) / Médio baixo (até $0,5 \sigma$ negativo) / Médio alto (até $0,5 \sigma$ positivo) / Alto (entre 0,5 e $1 \sigma$ positivo) / Muito alto (acima de $1 \sigma$ positivo). Escala de média 50 e desvio padrão ( $\sigma$ ) de 10 . A categoria "sem efeito" foi atribuída às variáveis (UF) sem relevância estatística para os indicadores de liderança e clima no nível de significância a $5 \%$ de probabilidade, o que ocorreu sobretudo na faixa entre -1,5 e 1,5, ou seja, sua contribuição para explicar a variação dos indicadores de liderança e clima é nula.

Notas: MT e PR, respectivamente, foram classificados como médio baixo e médio alto para liderança, mesmo dentro desta faixa. Semelhante ocorreu em Pernambuco para clima escolar, mas considerado "sem efeito" apesar do coeficiente fora desta faixa (colunas 3 e 4 ). Não houve UFs na categoria "alto" e "muito alto" dado o valor agregado, somente no nível por escola. Ademais, as classificações das leis estaduais foram discutidas ao longo do texto a partir da modalidade de seleção de diretores regulamentada em cada UF (coluna 1) e do maior percentual de respostas autodeclaradas dos diretores sobre como eles assumiram o cargo (coluna 2). A classificação da lei estadual utilizou como base as categorias de resposta do SAEB e considerou se a modalidade parece estar consolidada no período analisado (até dezembro/2016) ou em fase de transição para atender os critérios estabelecidos no PNE (processo seletivo e eleição). Os estados do PI e RJ tiveram diferença entre as modalidades com maior proporção em 2013 e 2015, demonstradas pelo símbolo "»". Fonte: Elaborada pelos autores. 
Apesar das grandes diferenças entre as políticas de provimento ao cargo de diretor em cada UFs, sua implementação nas escolas é um processo lento, seja em decorrência das dificuldades no processo de transição para as novas modalidades ou devido às nomeações ocorridas em datas anteriores à aprovação dos marcos legais. Neste sentido, ainda há uma alta proporção de escolas cujos diretores foram indicados politicamente, embora nenhuma lei a regulamente. Observa-se também que diversos estados vêm incorporando os critérios técnicos de mérito e desempenho e a consulta pública à comunidade escolar estabelecidos no PNE, o que parece impactar positivamente o indicador de clima escolar.

\section{CONCLUSÃO}

O presente estudo analisou se as diferentes políticas de provimento ao cargo de diretor interferem na percepção do corpo docente sobre a liderança desses profissionais e o clima escolar onde atuam. As escolas cujos diretores foram escolhidos por "concurso público apenas" apresentaram os maiores coeficientes médios para estes dois fatores, seguido pelo "processo seletivo e eleição", o que confirmou a hipótese inicial. Em contrapartida, a "indicação apenas" registrou os coeficientes médios mais baixos entre as modalidades de seleção. Posteriormente, as respostas aos questionários de contexto do Saeb de 2013 e de 2015 foram comparadas às políticas de provimento ao cargo de diretor nos 27 estados e no Distrito Federal.

Novamente, as maiores médias de clima escolar foram observadas em quatro UFs com predominância de critérios técnicos e/ou participativos para seleção de diretores, seja nas legislações ou na análise dos microdados ("concurso público apenas", "processo seletivo e eleição" ou "eleição apenas"). Já a "indicação apenas" prevalece nos três estados que registraram os menores valores de clima, embora a legislação preveja outras modalidades. Um padrão semelhante foi observado na análise da liderança do diretor, onde os maiores coeficientes ocorreram nas duas UFs com predomínio do "processo seletivo e eleição", sendo uma em convergência com a legislação e outra classificada como "eleição apenas". Também a "indicação apenas" foi a modalidade mais comum nos quatro estados com os menores coeficientes de liderança, apesar de suas leis terem regulamentado outras formas de seleção.

Outras variáveis analisadas também foram relevantes para explicar o comportamento dos coeficientes médios de clima escolar e de liderança do diretor que resultaram dos testes econométricos. No caso dos fatores de contexto do Inep, destacam-se a regularidade docente e a complexidade da gestão escolar, respectivamente, com polaridades positiva e negativa. O nível socioeconômico dos alunos teve efeito baixo para liderança e nenhum para clima. Entre os fatores associados ao perfil do diretor e de gestão, destacam-se a pós-graduação, o gênero feminino, o tempo neste cargo entre $11 \mathrm{e}$ 15 anos na mesma escola e os diretores que organizaram formações ou foram capacitados nos últimos 2 anos. De modo geral, os fatores contextuais tiveram maior impacto sobre o clima, abrangendo as relações estabelecidas entre os docentes, com foco no trabalho acadêmico. Por outro lado, o perfil do diretor e de gestão afetou mais a percepção de liderança, contemplando a atuação pedagógica ou administrativa e as relações pessoais com os professores.

Portanto, os resultados contribuem para compreender como as políticas de provimento ao cargo, quando são bem desenhadas e executadas, permitem selecionar diretores com as competências e as habilidades mais apropriadas para lidarem com os desafios escolares cotidianos. Porém, ressalta-se a necessidade de maior aprofundamento no tema e de busca por outras variáveis explicativas que 
interfiram na gestão escolar, visto que os efeitos das modalidades de seleção sobre a liderança do diretor e o clima escolar são limitados.

Neste sentido, observou-se uma variação significativa entre os resultados de cada UF, evidenciando que as especificidades locais influenciam a percepção dos professores sobre o clima e a liderança. Isso ocorre porque as variáveis de controle por UF agregam outros fatores não observáveis ou não explicitados neste trabalho que interferem nesse resultado. Recomenda-se que futuros estudos busquem identificar os fatores referentes à capacidade estatal e aos mecanismos de controle e de acompanhamento pedagógico das Secretarias de Educação, que possuem um potencial efeito na liderança do diretor e no clima escolar. Também merecem maior investigação outros fatores de ordem política e econômica dos estados.

É importante ainda conhecer quais mecanismos de avaliação vêm sendo aplicados nos processos seletivos dos 26 estados e do Distrito Federal, pois nomenclaturas semelhantes podem contemplar diferentes pré-requisitos e procedimentos de análise dos candidatos. Isso dificulta a comparabilidade entre as modalidades de seleção de maneira padronizada, seja em relação à categorização das legislações ou à classificação adotada nos microdados do Saeb, e representa outra limitação deste estudo. Por fim, destaca-se que a aprovação do PNE ainda é recente. Convém realizar um estudo longitudinal para medir o efeito agregado nas escolas que alteraram suas modalidades de seleção de diretores, fornecendo assim maiores evidências para os processos de tomada de decisão gerencial.

Frente aos resultados obtidos que demandam outros estudos mais aprofundados, o recorte analisado parece indicar aos gestores públicos que o "concurso público apenas" e o "processo seletivo e eleição" possuem efeito positivo sobre os indicadores de liderança e de clima escolar, contemplando aspectos fundamentais da gestão democrática. 


\section{REFERÊNCIAS}

Abrucio, F. L. (2010). Gestão escolar e qualidade da Educação: um estudo sobre dez escolas paulistas. In P. J. B. Louzano (Ed.), Estudos \& Pesquisas Educacionais (pp. 241-274). São Paulo, SP: Fundação Vitor Civita.

Alves, M. T. G., \& Franco, C. (2008). A pesquisa em eficácia escolar no Brasil: evidências sobre o efeito das escolas e fatores associados à eficácia escolar. In N. Brooke, \& J. F. Soares (Orgs.), Pesquisa em eficácia escolar: origens e trajetórias (pp. 482-500). Belo Horizonte, MG: UFMG.

Alves, M. T. G., Xavier, F. P., Barbosa, L. E., Caldeira, B. F., Silva, C. A. S., \& Soares, J. F. (2015, agosto). Fatores contextuais das escolas da educação básica: dados, métodos e aplicações. In Anais de Reuniões da ABAVE 8 (No. 2. pp. 57-76), Florianópolis, SC.

Ghanem, E. G. G., Jr. (1995). Participação popular na gestão escolar: bibliografia. São Paulo, SP: Ação Educativa.

Gremaud, A. P., Pazello, E. T., \& Maluf, B. T (2016, agosto). O impacto da indicação política do diretor no desempenho educacional. In Anais de Reuniões da ABAVE 8 (No. 2. pp. 313-336), Florianópolis, SC.

Instituto Brasileiro de Geografia e Estatística. (2015). Perfil dos Estados e dos Municípios Brasileiros: cultura 2014. Rio de Janeiro, RJ: Autor.

Instituto Nacional de Estudos e Pesquisas Educacionais Anísio Teixeira. (2015). Plano Nacional de Educação PNE 2014-2024: Linha de Base. Brasília, DF: Autor.

Instituto Nacional de Estudos e Pesquisas Educacionais Anísio Teixeira. (2017, março 18). Microdados Saeb (Aneb/Prova Brasil) de 2013 e de 2015. Brasília, DF: Autor. Recuperado de http:// portal.inep.gov.br/microdados

Leithwood, K., \& Jantzi, D. (2009). A review of empirical evidence about school size effects: A policy perspective. Review of educational research, 79(1), 464-490.

Libâneo, J. C (2001). Organização e gestão da escola: teoria e prática. Goiânia, GO: Editora Alternativa.

Lück, H. (2009). Dimensões de gestão escolar e suas competências. Curitiba, PR: Positivo.
Lück, H. (2011). Mapeamento de práticas de seleção e capacitação de diretores escolares. São Paulo, SP: Fundação Vitor Civita.

Maia, G. Z. A., \& Manfio, A. (2010). O provimento do cargo de gestor escolar e a qualidade de ensino: análise de publicações nacionais (1990-2005). RBPAE - Revista Brasileira de Política e Administração da Educação, 26(3), 477-494.

Marks, H. M., \& Printy, S. M. (2003). Principal leadership and school performance: An integration of transformational and instructional leadership. Educational administration quarterly, 39(3), 370-397.

Mortimore, P., Sammons, P., \& Ecob, R. (1988). Expressing the magnitude of school effects: A reply to Peter Preece. Research Papers in Education, 3(2), 99-101.

Oliveira, A. C. P. (2015). As relações entre direção, liderança e clima escolar em escolas municipais do Rio de Janeiro (Tese de Doutorado). Pontifícia Universidade Católica do Rio de Janeiro, Rio de Janeiro, RJ.

Oliveira, A. C. P., \& Carvalho, C. P. (2015, novembro). Gestão escolar, liderança do diretor e resultados educacionais no Brasil. In Anais da $37^{\circ}$ Reunião Nacional da ANPED, Florianópolis, SC.

Oliveira, A. C. P., \& Waldhelm, A. P. S. (2016). Liderança do diretor, clima escolar e o desempenho dos alunos: qual a relação. Ensaio: Avaliação $e$ Políticas Públicas em Educação, 24(93), 824-844. Recuperado de http://www.scielo.br/pdf/ensaio/ v24n93/1809-4465-ensaio-24-93-0824.pdf

Organização das Nações Unidas para a Educação, a Ciência e a Cultura. (2019). Qualidade da infraestrutura das escolas públicas do ensino fundamental no Brasil. Brasília, DF: Autor.

Organização das Nações Unidas para a Educação, a Ciência e a Cultura. (2017). Desigualdades de aprendizado entre alunos das escolas públicas brasileiras. Evidências da Prova Brasil (2007 a 2013). Brasília, DF: Autor.

Pereda, P., Lucchesi, A., Mendes, K., \& Bresolin, A. (2015, dezembro). Avaliação do impacto do processo de seleção de diretores nas escolas públicas brasileiras. In Anais do $43^{\circ}$ Encontro Nacional de Economia, Florianópolis, SC. 
Rutter, M., Maughan, B., Mortimore, P., Ouston, J., \& Smith, A. (2008). Estudos anteriores. In N. Brooke, \& J. F. Soares (Orgs.), Pesquisa em eficácia escolar: origem e trajetórias (pp. 142-152). Belo Horizonte, MG: UFMG.

Samejima, F. (1969). Estimation of latent ability using a response pattern of graded responses (Psychometric Monograph, No. 17). Richmond, VA: Psychometric Society.

Sammons, P. (2008). As características-chave das escolas eficazes. In: Brooke, N., \& Soares, J. F. (Orgs.). Pesquisa em eficácia escolar: origens e trajetórias (pp. 335-387). Belo Horizonte, MG: UFMG.

Soares, J. F. (2004). O Efeito da Escola no Desempenho Cognitivo de seus Alunos. REICE - Revista Electrónica Iberoamericana sobre Calidad, Eficacia y Cambio en
Educación, 2(2), 83-104. Recuperado de https:// www.redalyc.org/pdf/551/55120207.pdf

Teddlie, C., \& Reynolds, D. (2000). The International handbook of school effectiveness research. London, EN: Falmer Press.

Teddlie, C., \& Stringfield, S. (1993). Schools make a difference: lessons learned from a 10-year study of school effects. New York, NY: Teachers College Press.

Urick, A., \& Bowers, A. J. (2014). What are the different types of principals across the United States? A latent class analysis of principal perception of leadership. Educational Administration Quarterly, 50(1) 96-134.

Wooldridge, J. M. (2016). Introdução à econometria: uma abordagem moderna. São Paulo, SP: Cengage Learning.

\section{Bruno Sendra de Assis}

https://orcid.org/0000-0001-9925-3080

Doutorando em Ciência Política pela Universidade de São Paulo (USP); Mestre em Administração Pública e Governo pela Fundação Getulio Vargas (FGV EAESP); Especialista em Gestão Estratégica e Econômica de Projetos pela Fundação Getulio Vargas (FGV EAESP).E-mail: brunoassis@usp.br

\section{Nelson Marconi}

https://orcid.org/0000-0002-1399-5305

Doutor em economia de empresas pela Fundação Getulio Vargas (FGV EAESP); Professor da Fundação Getulio Vargas (FGV EAESP); Coordenador do Centro de Estudos do Novo Desenvolvimentismo na mesma instituição. E-mail: nelson.marconi@fgv.br 


\section{APÊNDICE}

\section{Legislações Estaduais de Provimento ao Cargo de Diretor}

A classificação das legislações estaduais e do Distrito Federal utilizou como base as categorias de resposta do Saeb para fins de comparação entre a modalidade de seleção do diretor adotada, ou seja, se há diferença entre os processos de formulação e de implementação destas políticas. Também foi avaliado se essa modalidade parece estar consolidada no período analisado, até dezembro de 2016, ou em fase de transição para atendimento aos critérios estabelecidos no PNE (processo seletivo e eleição).

\section{QUADRO 3 ESTADOS COM 'ELEIÇÃO APENAS' PARA 0 CARGO DE DIRETOR (CONSOLIDADA)}

\begin{tabular}{|c|c|c|c|c|c|c|}
\hline UF & $\begin{array}{l}\text { Plano Estadual } \\
\text { de Educação }\end{array}$ & Lei / Ano & $\begin{array}{l}\text { Plano de Carreira / } \\
\text { Sistema de Ensino }\end{array}$ & Lei / Ano & $\begin{array}{l}\text { Lei Gestão Democrática / } \\
\text { Seleção de Diretores }\end{array}$ & Lei / Ano \\
\hline AP & $\begin{array}{l}\text { Fortalecer a gestão } \\
\text { democrática no } \\
\text { sistema de ensino. }\end{array}$ & $\begin{array}{l}\text { Lei } \mathrm{n}^{0} 1.907 \\
\text { /2015 }\end{array}$ & $\begin{array}{c}\text { Eleição dos } \\
\text { dirigentes escolares, } \\
\text { nos termos de Lei } \\
\text { específica. }\end{array}$ & $\begin{array}{l}\text { Lei } n^{\circ} \\
0949 \\
/ 2005\end{array}$ & $\begin{array}{l}\text { Eleição pela comunidade } \\
\text { escolar por votação direta } \\
\text { e secreta. }\end{array}$ & $\begin{array}{l}\text { Lei } n^{\circ} \\
1.503 \\
/ 2010\end{array}$ \\
\hline PA & $\begin{array}{c}\text { Eleição direta para } \\
\text { diretores com } \\
\text { participação da } \\
\text { comunidade escolar. }\end{array}$ & $\begin{array}{l}\text { Lei } n^{0} 8.186 \\
\text { /2015 }\end{array}$ & $\begin{array}{c}\text { Servidor graduado na } \\
\text { habilitação específica } \\
\text { em Administração } \\
\text { Escolar. }\end{array}$ & $\begin{array}{l}\text { Lei } n^{\circ} \\
5.351 \\
/ 1986\end{array}$ & $\begin{array}{l}\text { Eleição direta, por chapa, } \\
\text { para efetivos com } 3 \text { anos } \\
\text { na rede e plano de gestão. }\end{array}$ & $\begin{array}{l}\text { Lei } n^{\circ} \\
7.855 \\
/ 2014\end{array}$ \\
\hline PB & $\begin{array}{l}\text { Escolha realizada, } \\
\text { pela comunidade } \\
\text { escolar, mediante } \\
\text { processo eletivo. }\end{array}$ & $\begin{array}{l}\text { Lei } \mathrm{n}^{0} 10.488 \\
\qquad / 2015\end{array}$ & Sem referência. & $\begin{array}{l}\text { Lei n } \\
7.419 \\
\text { /2003 }\end{array}$ & $\begin{array}{l}\text { Escolha pela comunidade } \\
\text { escolar, mediante } \\
\text { processo eletivo. }\end{array}$ & $\begin{array}{l}\text { Lei } n^{0} \\
7.983 \\
/ 2006\end{array}$ \\
\hline G0 & $\begin{array}{l}\text { Eleições diretas } \\
\text { para gestores. }\end{array}$ & $\begin{array}{l}\text { Lei } n^{0} 18.969 \\
\text { /2015 }\end{array}$ & $\begin{array}{c}\text { Eleição pela } \\
\text { comunidade escolar, } \\
\text { por voto direto. }\end{array}$ & $\begin{array}{l}\text { Lei } n^{\circ} \\
13.909 \\
\text { /2001 }\end{array}$ & $\begin{array}{l}\text { Eleição pela comunidade } \\
\text { escolar, por voto direto, } \\
\text { secreto e facultativo. }\end{array}$ & $\begin{array}{l}\text { Lei } n^{0} \\
13.564 \\
/ 1999\end{array}$ \\
\hline MT & $\begin{array}{l}\text { Eleição direta de } \\
\text { gestores pela } \\
\text { comunidade. }\end{array}$ & $\begin{array}{l}\text { Lei } n^{0} 10.111 \\
\text { /2014 }\end{array}$ & $\begin{array}{l}\text { Servidores de } \\
\text { carreira, efetivos, } \\
\text { estáveis, ativos, em } \\
\text { regime exclusivo. }\end{array}$ & $\begin{array}{l}\text { Lei C. } \\
n^{0} 211 \\
/ 2005\end{array}$ & $\begin{array}{c}\text { Indicação da comunidade } \\
\text { escolar mediante votação } \\
\text { direta. }\end{array}$ & $\begin{array}{l}\text { Lei C. } n^{0} \\
\quad 49 \\
/ 1998\end{array}$ \\
\hline$M G$ & $\begin{array}{c}\text { Consolidar e } \\
\text { aperfeiçoar o } \\
\text { processo de escolha } \\
\text { democrática de } \\
\text { diretores } \\
\text { * (Ref. Plano Decenal } \\
\text { - PEE não aprovado } \\
\text { até dez/16). }\end{array}$ & $\begin{array}{l}\text { Lei } n^{0} 19.481 \\
\text { /2011 }\end{array}$ & Sem referência. & $\begin{array}{l}\text { Lei } n^{\circ} \\
15.293 \\
\text { /2004 }\end{array}$ & $\begin{array}{l}\text { Escolha do diretor via } \\
\text { chapa completa. }\end{array}$ & $\begin{array}{c}\text { Resolução } \\
n^{0} 2.795 \\
\text { /2015 }\end{array}$ \\
\hline
\end{tabular}




\begin{tabular}{|c|c|c|c|c|c|c|}
\hline UF & $\begin{array}{l}\text { Plano Estadual } \\
\text { de Educação }\end{array}$ & Lei / Ano & $\begin{array}{l}\text { Plano de Carreira / } \\
\text { Sistema de Ensino }\end{array}$ & Lei / Ano & $\begin{array}{l}\text { Lei Gestão Democrática / } \\
\text { Seleção de Diretores }\end{array}$ & Lei / Ano \\
\hline RJ & $\begin{array}{l}\text { Formular projetos } \\
\text { político pedagógicos } \\
\text { para fomentar a } \\
\text { gestão democrática } \\
\text { (novo PEE não } \\
\text { aprovado até } \\
\text { dez/16). }\end{array}$ & $\begin{array}{l}\text { Lei } n^{0} 5.597 \\
\quad / 2009\end{array}$ & Sem referência. & $\begin{array}{l}\text { Lei } n^{0} \\
1.614 \\
/ 1990\end{array}$ & $\begin{array}{l}\text { Processos consultivos de } \\
\text { indicação de membros do } \\
\text { magistério. }\end{array}$ & $\begin{array}{l}\text { Lei } n^{0} \\
7.299 \\
/ 2016\end{array}$ \\
\hline RS & $\begin{array}{l}\text { Provimento } \\
\text { democrático da } \\
\text { função de gestor, } \\
\text { com previsão de } \\
\text { recursos da União. }\end{array}$ & $\begin{array}{l}\text { Lei } n^{0} 14.705 \\
\quad / 2015\end{array}$ & Sem referência. & $\begin{array}{l}\text { Lei } n^{0} \\
6.672 \\
/ 1974\end{array}$ & $\begin{array}{l}\text { Votação direta, de chapa, } \\
\text { pela comunidade escolar e } \\
\text { curso de qualificação. }\end{array}$ & $\begin{array}{l}\text { Lei } n^{0} \\
10.576 \\
/ 1995\end{array}$ \\
\hline
\end{tabular}

Fonte: Elaborado pelos autores.

\section{QUADRO 4 ESTADOS COM 'ELEIÇÃO APENAS' PARA O CARGO DE DIRETOR (TRANSIÇÃO)}

\begin{tabular}{|c|c|c|c|c|c|c|}
\hline UF & $\begin{array}{l}\text { Plano Estadual } \\
\text { de Educação }\end{array}$ & Lei / Ano & $\begin{array}{l}\text { Plano de Carreira / } \\
\text { Sistema de Ensino }\end{array}$ & Lei / Ano & $\begin{array}{l}\text { Lei Gestão Democrática / } \\
\text { Seleção de Diretores }\end{array}$ & Lei / Ano \\
\hline RO & $\begin{array}{l}\text { Eleição p/ critérios } \\
\text { técnicos de mérito, } \\
\text { desempenho } \\
\text { e participação } \\
\text { comunidade. }\end{array}$ & $\begin{array}{l}\text { Lei } n^{0} 3.565 \\
\text { /2015 }\end{array}$ & $\begin{array}{l}\text { Eleição de diretores } \\
\text { com formação } \\
\text { em Pedagogia ou } \\
\text { Licenciatura. }\end{array}$ & $\begin{array}{l}\text { Lei C. nº } 680 \\
\text { /2012 }\end{array}$ & $\begin{array}{l}\text { Eleições diretas para } \\
\text { diretor com participação } \\
\text { da comunidade escolar. }\end{array}$ & $\begin{array}{c}\text { Decreto } n^{0} \\
16.202 \\
/ 2011\end{array}$ \\
\hline$A L$ & $\begin{array}{l}\text { Eleição p critérios } \\
\text { técnicos de mérito, } \\
\text { desempenho } \\
\text { e participação } \\
\text { comunidade. }\end{array}$ & $\begin{array}{l}\text { Lei } n^{0} 7.795 \\
\text { /2016 }\end{array}$ & Sem referência. & $\begin{array}{l}\text { Lei nº.197 } \\
\text { /2000 }\end{array}$ & $\begin{array}{l}\text { Eleição pela comunidade } \\
\text { escolar por voto universal } \\
\text { direto e secreto. }\end{array}$ & $\begin{array}{l}\text { Lei } n^{0} 6.628 \\
\quad / 2005\end{array}$ \\
\hline PI & $\begin{array}{l}\text { Eleição direta } \\
\text { para efetivos e } \\
\text { qualificados na } \\
\text { LDB com teste de } \\
\text { conhecimento. }\end{array}$ & $\begin{array}{l}\text { Lei } n^{\circ} 6.733 \\
\text { /2015 }\end{array}$ & $\begin{array}{l}\text { Eleição direta para } \\
\text { diretor, na forma de } \\
\text { regulamento. }\end{array}$ & $\begin{array}{l}\text { Lei C. } n^{0} 71 \\
\qquad / 2006\end{array}$ & $\begin{array}{l}\text { Eleição direta por } 2 \text { anos } \\
\text { pela comunidade escolar, } \\
\text { com direito à reeleição. }\end{array}$ & $\begin{array}{c}\text { Decreto } \mathrm{n}^{0} \\
12.766 \\
\text { /2007 }\end{array}$ \\
\hline RN & $\begin{array}{c}\text { Teste de } \\
\text { conhecimentos } \\
\text { específicos, } \\
\text { desempenho e } \\
\text { consulta pública } \\
\text { (eleição). }\end{array}$ & $\begin{array}{c}\text { Lei } n^{0} 10.049 \\
\text { /2016 }\end{array}$ & $\begin{array}{c}\text { Gestão democrática } \\
\text { do ensino na forma } \\
\text { de lei. }\end{array}$ & $\begin{array}{l}\text { Lei C. n } 322 \\
\text { /2006 }\end{array}$ & $\begin{array}{l}\text { Candidatos eleitos pelos } \\
\text { membros do Colégio } \\
\text { Eleitoral. }\end{array}$ & $\begin{array}{l}\text { Lei C. } n^{0} 290 \\
\quad / 2005\end{array}$ \\
\hline
\end{tabular}


RAP | Efeito das políticas de provimento ao cargo de diretor na gestão escolar

\begin{tabular}{|c|c|c|c|c|c|c|}
\hline UF & $\begin{array}{l}\text { Plano Estadual } \\
\text { de Educação }\end{array}$ & Lei / Ano & $\begin{array}{l}\text { Plano de Carreira / } \\
\text { Sistema de Ensino }\end{array}$ & Lei / Ano & $\begin{array}{l}\text { Lei Gestão Democrática / } \\
\text { Seleção de Diretores }\end{array}$ & Lei / Ano \\
\hline DF & $\begin{array}{c}\text { Eleição é } \\
\text { importante, mas } \\
\text { precisa estar } \\
\text { associada a outras } \\
\text { políticas. }\end{array}$ & $\begin{array}{l}\text { Lei } n^{0} 5.499 \\
\text { /2015 }\end{array}$ & Sem referência. & $\begin{array}{l}\text { Lei nº } 5.105 \\
\text { /2013 }\end{array}$ & $\begin{array}{l}\text { Eleitos por voto direto e } \\
\text { secreto participam de } \\
\text { curso de gestão escolar. }\end{array}$ & $\begin{array}{l}\text { Lei } n^{\circ} 4.751 \\
\quad / 2012\end{array}$ \\
\hline MS & $\begin{array}{l}\text { Eleição p/ critérios } \\
\text { técnicos de mérito, } \\
\text { desempenho } \\
\text { e participação } \\
\text { comunidade. }\end{array}$ & $\begin{array}{c}\text { Lei nº } 4.621 \\
\text { /2014 }\end{array}$ & $\begin{array}{c}\text { Eleição direta na } \\
\text { comunidade escolar, } \\
\text { com habilitação nível } \\
\text { superior. }\end{array}$ & $\begin{array}{l}\text { Lei C. nº } 087 \\
\qquad / 2000\end{array}$ & $\begin{array}{l}\text { Voto direto proporcional e } \\
\text { secreto na forma da lei ou } \\
\text { regulamento próprio. }\end{array}$ & $\begin{array}{l}\text { Lei } n^{0} 2.787 \\
\quad / 2003\end{array}$ \\
\hline PR & $\begin{array}{c}\text { Critérios de } \\
\text { formação e } \\
\text { desempenho e à } \\
\text { consulta pública à } \\
\text { comunidade. }\end{array}$ & $\begin{array}{l}\text { Lei } n^{0} 18.492 \\
\text { /2015 }\end{array}$ & $\begin{array}{c}\text { Consulta à } \\
\text { comunidade escolar } \\
\text { para a designação } \\
\text { dos diretores. }\end{array}$ & $\begin{array}{l}\text { Lei C. } n^{0} 103 \\
\text { /2004 }\end{array}$ & $\begin{array}{l}\text { Delegação da escolha à } \\
\text { comunidade escolar, em } \\
\text { consulta simultânea. }\end{array}$ & $\begin{array}{l}\text { Lei } n^{0} \\
18.590 \\
/ 2015\end{array}$ \\
\hline
\end{tabular}

Fonte: Elaborado pelos autores.

\section{QUADRO 5 ESTADOS COM 'CONCURSO PÚBLICO APENAS' PARA 0 CARGO DE DIRETOR}

\begin{tabular}{|c|c|c|c|c|c|c|}
\hline UF & $\begin{array}{l}\text { Plano Estadual } \\
\text { de Educação }\end{array}$ & Lei / Ano & $\begin{array}{l}\text { Plano de Carreira / } \\
\text { Sistema de Ensino }\end{array}$ & Lei / Ano & $\begin{array}{l}\text { Lei Gestão Democrática / } \\
\text { Seleção de Diretores }\end{array}$ & Lei / Ano \\
\hline SP & $\begin{array}{l}\text { Garantir o } \\
\text { provimento ao cargo } \\
\text { por critério meritório, } \\
\text { via Concurso público } \\
\text { de prova e títulos. }\end{array}$ & $\begin{array}{c}\text { Lei } n^{0} 16.279 \\
\text { /2016 }\end{array}$ & $\begin{array}{l}\text { Provimento ao } \\
\text { cargo de diretor por } \\
\text { Concurso Público } \\
\text { de provas e títulos } \\
\text { (Nomeação). }\end{array}$ & $\begin{array}{l}\text { Lei C. nº } 836 \\
\quad / 1997\end{array}$ & $\begin{array}{l}\text { Avaliação especial de } \\
\text { desempenho com curso } \\
\text { específico de formação } \\
\text { em estágio probatório. }\end{array}$ & $\begin{array}{l}\text { Lei C. } n^{0} 1.256 \\
\qquad / 2015\end{array}$ \\
\hline
\end{tabular}

Fonte: Elaborado pelos autores. 
RAP | Efeito das políticas de provimento ao cargo de diretor na gestão escolar

\section{QUADRO 6 ESTADOS COM 'INDICAÇÃO APENAS’ PARA O CARGO DE DIRETOR}

\begin{tabular}{|c|c|c|c|c|c|c|}
\hline UF & $\begin{array}{l}\text { Plano Estadual } \\
\text { de Educação }\end{array}$ & Lei / Ano & $\begin{array}{l}\text { Plano de Carreira / } \\
\text { Sistema de Ensino }\end{array}$ & Lei / Ano & $\begin{array}{l}\text { Lei Gestão Democrática / } \\
\text { Seleção de Diretores }\end{array}$ & Lei / Ano \\
\hline $\mathrm{RR}$ & $\begin{array}{c}\text { Assegurar a } \\
\text { efetivação da gestão } \\
\text { democrática no } \\
\text { prazo de } 2 \text { anos, } \\
\text { associada a critérios } \\
\text { técnicos de mérito e } \\
\text { de desempenho. }\end{array}$ & $\begin{array}{l}\text { Lei } n^{0} 1.008 \\
\quad / 2015\end{array}$ & $\begin{array}{l}\text { Professores do } \\
\text { estado que atendam } \\
\text { aos critérios de } \\
\text { formação profissional } \\
\text { com base na lei. }\end{array}$ & $\begin{array}{l}\text { Lei } n^{0} 892 / \\
2013\end{array}$ & $\begin{array}{l}\text { Avaliação especial de } \\
\text { desempenho com curso } \\
\text { específico de formação } \\
\text { em estágio probatório. }\end{array}$ & $\begin{array}{l}\text { Lei no } \\
810 / \\
2011\end{array}$ \\
\hline
\end{tabular}

Fonte: Elaborado pelos autores.

\section{QUADRO 7 ESTADOS COM 'PROCESSO SELETIVO APENAS' PARA 0 CARGO DE DIRETOR}

\begin{tabular}{|c|c|c|c|c|c|c|}
\hline UF & $\begin{array}{l}\text { Plano Estadual } \\
\text { de Educação }\end{array}$ & Lei / Ano & $\begin{array}{l}\text { Plano de Carreira / } \\
\text { Sistema de Ensino }\end{array}$ & Lei / Ano & $\begin{array}{l}\text { Lei Gestão Democrática } \\
\text { / Seleção de Diretores }\end{array}$ & Lei / Ano \\
\hline AM & $\begin{array}{l}\text { Processo de seleção } \\
\text { pública de diretores } \\
\text { escolares baseado } \\
\text { em critérios } \\
\text { técnicos. }\end{array}$ & $\begin{array}{c}\text { Lei } n^{0} 4.183 / \\
2015\end{array}$ & Sem referência. & $\begin{array}{l}\text { Lei no } \\
3951 / \\
2013\end{array}$ & $\begin{array}{c}\text { Gestores escolhidos } \\
\text { e indicados pela } \\
\text { autoridade competente, } \\
\text { submetidos a processo } \\
\text { seletivo. }\end{array}$ & $\begin{array}{c}\text { Resolução } \\
\text { n 122/ } \\
2010\end{array}$ \\
\hline
\end{tabular}

Fonte: Elaborado pelos autores. 
RAP | Efeito das políticas de provimento ao cargo de diretor na gestão escolar

\section{QUADRO 8 ESTADOS COM 'PROCESSO SELETIVO E ELEIÇÃO' PARA O CARGO DE DIRETOR (CONSOLIDADA)}

\begin{tabular}{|c|c|c|c|c|c|c|}
\hline UF & $\begin{array}{l}\text { Plano Estadual } \\
\text { de Educação }\end{array}$ & Lei / Ano & $\begin{array}{l}\text { Plano de Carreira / } \\
\text { Sistema de Ensino }\end{array}$ & Lei / Ano & $\begin{array}{l}\text { Lei Gestão Democrática } \\
\text { / Seleção de Diretores }\end{array}$ & Lei / Ano \\
\hline CE & $\begin{array}{l}\text { Critérios técnicos } \\
\text { de mérito e } \\
\text { desempenho, com } \\
\text { provas de títulos, } \\
\text { e participação da } \\
\text { comunidade escolar. }\end{array}$ & $\begin{array}{l}\text { Lei no } 16.025 \\
\quad / 2016\end{array}$ & Sem referência. & $\begin{array}{l}\text { Lei } n^{0} \\
12.066 \\
/ 1993\end{array}$ & $\begin{array}{l}\text { Avaliação escrita } \\
\text { e exame de títulos } \\
\text { (eliminatória) e eleição } \\
\text { direta e secreta pela } \\
\text { comunidade escolar. }\end{array}$ & $\begin{array}{c}\text { Lei } n^{0} \\
13.513 / 2004\end{array}$ \\
\hline PE & $\begin{array}{l}\text { Critérios técnicos } \\
\text { e de mérito e } \\
\text { desempenho e } \\
\text { consulta pública à } \\
\text { comunidade escolar. }\end{array}$ & $\begin{array}{c}\text { Lei } n^{0} \\
15.533 / 2015\end{array}$ & Sem referência. & $\begin{array}{l}\text { Lei } n^{0} \\
11.559 \\
/ 1998\end{array}$ & $\begin{array}{c}\text { Designação do } \\
\text { governador mediante } \\
\text { participação em etapas } \\
\text { seletiva, consultiva e } \\
\text { formativa. }\end{array}$ & $\begin{array}{c}\text { Decreto } n^{0} \\
38.103 / \\
2012\end{array}$ \\
\hline SE & $\begin{array}{l}\text { Critérios técnicos } \\
\text { de mérito e } \\
\text { desempenho, curso } \\
\text { de especialização } \\
\text { com plano de } \\
\text { trabalho e eleição } \\
\text { direta. }\end{array}$ & $\begin{array}{l}\text { Lei no } 8.025 / \\
2015\end{array}$ & $\begin{array}{l}\text { Seleção prévia } \\
\text { que avalie } \\
\text { conhecimento } \\
\text { específicos e } \\
\text { proposta de gestão } \\
\text { para a comunidade } \\
\text { escolar. }\end{array}$ & $\begin{array}{l}\text { Lei C. } n^{0} \\
61 / \\
2001\end{array}$ & $\begin{array}{l}\text { Concurso público de } \\
\text { provas e títulos. }\end{array}$ & $\begin{array}{c}\text { Decreto } n^{0} \\
16.396 / \\
1997\end{array}$ \\
\hline SC & $\begin{array}{l}\text { Garantir em lei } \\
\text { específica diretrizes } \\
\text { para a gestão } \\
\text { democrática da } \\
\text { educação. }\end{array}$ & $\begin{array}{l}\text { Lei } n^{0} 16.704 \\
\quad / 2015\end{array}$ & $\begin{array}{l}\text { Gratificação para } \\
\text { exercício da função } \\
\text { de diretor. }\end{array}$ & $\begin{array}{c}\text { Lei C. nº } \\
668 / 2015\end{array}$ & $\begin{array}{l}\text { Proposta de planos } \\
\text { de gestão escolar } \\
\text { para escolha da } \\
\text { comunidade. }\end{array}$ & $\begin{array}{c}\text { Decreto } n^{\circ} \\
1.794 \\
/ 2013\end{array}$ \\
\hline ES & $\begin{array}{l}\text { Critérios técnicos e } \\
\text { consulta pública à } \\
\text { comunidade escolar. }\end{array}$ & $\begin{array}{l}\text { Lei } \mathrm{n}^{0} 10.382 \\
\quad / 2015\end{array}$ & Sem referência. & $\begin{array}{c}\text { Decreto } n^{0} \\
3046-R \\
/ 2012\end{array}$ & $\begin{array}{l}\text { Processo seletivo pelo } \\
\text { Órgão Gestor e eleição } \\
\text { pelo Conselho Escolar. }\end{array}$ & $\begin{array}{l}\text { Lei no } 5.471 \\
\quad / 1997\end{array}$ \\
\hline
\end{tabular}

Fonte: Elaborado pelos autores. 


\section{QUADRO 9 ESTADOS COM 'PROCESSO SELETIVO E ELEIÇÃO’ PARA O CARGO DE DIRETOR (TRANSIÇÃO)}

\begin{tabular}{|c|c|c|c|c|c|c|}
\hline UF & $\begin{array}{l}\text { Plano Estadual } \\
\text { de Educação }\end{array}$ & $\begin{array}{l}\text { Lei / } \\
\text { Ano }\end{array}$ & $\begin{array}{l}\text { Plano de Carreira / } \\
\text { Sistema de Ensino }\end{array}$ & Lei / Ano & $\begin{array}{l}\text { Lei Gestão Democrática } \\
\text { / Seleção de Diretores }\end{array}$ & $\begin{array}{l}\text { Lei / } \\
\text { Ano }\end{array}$ \\
\hline$A C$ & $\begin{array}{c}\text { Curso de } \\
\text { capacitação para } \\
\text { gestores com } \\
\text { exame final de } \\
\text { certificação e } \\
\text { eleição direta pela } \\
\text { comunidade. }\end{array}$ & $\begin{array}{l}\text { Lei } n^{0} 2.965 \\
\quad / 2015\end{array}$ & $\begin{array}{l}\text { Funções de gestão } \\
\text { escolar serão } \\
\text { disciplinadas em } \\
\text { lei específica } \\
\text { sobre a gestão } \\
\text { democrática. }\end{array}$ & $\begin{array}{l}\text { Lei C. } n^{0} \\
274 / \\
2013\end{array}$ & $\begin{array}{c}\text { Processo de } \\
\text { certificação, eleição } \\
\text { com participação da } \\
\text { comunidade escolar e } \\
\text { formação continuada. }\end{array}$ & $\begin{array}{c}\text { Lei } n^{0} 3.141 / \\
2016\end{array}$ \\
\hline TO & $\begin{array}{l}\text { Critérios técnicos } \\
\text { de formação, } \\
\text { experiência, } \\
\text { desempenho e } \\
\text { consulta pública à } \\
\text { comunidade. }\end{array}$ & $\begin{array}{l}\text { Lei nº } 2.977 / \\
2015\end{array}$ & $\begin{array}{c}\text { Gestão } \\
\text { democrática } \\
\text { que participem } \\
\text { Associações } \\
\text { de Apoio com } \\
\text { docentes, } \\
\text { pais, alunos e } \\
\text { servidores. }\end{array}$ & $\begin{array}{l}\text { Lei nº } \\
2.859 / \\
2014\end{array}$ & $\begin{array}{l}\text { Prova objetiva de } \\
\text { conhecimentos, } \\
\text { plano de trabalho e } \\
\text { documentação, eleição } \\
\text { direta e secreta. }\end{array}$ & $\begin{array}{c}\text { Edital } n^{\circ} \\
0058 / \\
2015\end{array}$ \\
\hline BA & $\begin{array}{l}\text { Nomeação por } \\
\text { critérios técnicos } \\
\text { de mérito e } \\
\text { desempenho, com } \\
\text { a participação } \\
\text { comunidade. }\end{array}$ & $\begin{array}{l}\text { Lei nº 13.559/ } \\
2016\end{array}$ & $\begin{array}{l}\text { Efetivos com } \\
\text { licenciatura } \\
\text { plena, aprovados } \\
\text { em processo } \\
\text { seletivo interno e } \\
\text { certificação. }\end{array}$ & $\begin{array}{l}\text { Lei } n^{0} \\
8.261 / \\
2002\end{array}$ & $\begin{array}{c}\text { Processo seletivo } \\
\text { realizado pela escola, } \\
\text { certificados em teste } \\
\text { de conhecimento sobre } \\
\text { gestão escolar. }\end{array}$ & $\begin{array}{c}\text { Decreto } n^{0} \\
16.385 / 2015\end{array}$ \\
\hline MA & $\begin{array}{l}\text { Critérios técnicos } \\
\text { e de mérito e } \\
\text { desempenho e } \\
\text { participação direta } \\
\text { da comunidade } \\
\text { escolar. }\end{array}$ & $\begin{array}{c}\text { Lei } n^{0} 10.099 / \\
2014\end{array}$ & $\begin{array}{l}\text { Eleição direta } \\
\text { e exigência de } \\
\text { qualificação em } \\
\text { curso de gestão } \\
\text { escolar. }\end{array}$ & $\begin{array}{l}\text { Lei } n^{0} \\
9.860 / \\
2013\end{array}$ & $\begin{array}{l}\text { Carta de intenção, } \\
\text { exame de certificação } \\
\text { em curso, consulta } \\
\text { democrática e contrato } \\
\text { de gestão. }\end{array}$ & $\begin{array}{c}\text { Decreto } n^{0} \\
30.619 / \\
2015\end{array}$ \\
\hline
\end{tabular}

Fonte: Elaborado pelos autores.

\section{ESTATÍSTICA DESCRITIVA E MODELOS DE TRI}

Abaixo são apresentadas as tabelas e gráficos utilizadas neste estudo e permitem uma análise mais aprofundada sobre os dados utilizados para construção do modelo de TRI e aplicação do modelo de regressão linear, bem como para análise das legislações estaduais sobre provimento ao cargo de diretor. Também incluem os percentuais de distribuição das modalidades de seleção por UF em 2013 e 2015. 


\section{TABELA 3 PROVIMENTO AO CARGO DE DIRETOR POR UF NO SAEB 2013 E 2015}

\begin{tabular}{|c|c|c|c|c|c|c|c|c|c|c|c|c|c|c|}
\hline \multirow{2}{*}{ UF } & \multicolumn{2}{|c|}{ Concurso } & \multicolumn{2}{|c|}{ Eleição } & \multicolumn{2}{|c|}{ Indicação } & \multicolumn{2}{|c|}{ Processo sel. } & \multicolumn{2}{|c|}{ Proc_eleição } & \multicolumn{2}{|c|}{ Proc_indic. } & \multicolumn{2}{|c|}{ Outra_For. } \\
\hline & 2013 & 2015 & 2013 & 2015 & 2013 & 2015 & 2013 & 2015 & 2013 & 2015 & 2013 & 2015 & 2013 & 2015 \\
\hline$A C$ & $1,0 \%$ & $0,0 \%$ & $4 \%$ & $8,0 \%$ & $5,4 \%$ & $5 \%$ & $0,0 \%$ & $1,5 \%$ & $81,3 \%$ & $75,9 \%$ & $1,0 \%$ & $3,0 \%$ & $2,0 \%$ & $2,0 \%$ \\
\hline$A L$ & $0,0 \%$ & $0,0 \%$ & $81,2 \%$ & $77,4 \%$ & $7,9 \%$ & $13,6 \%$ & $0,0 \%$ & $1,1 \%$ & $7,4 \%$ & $2,8 \%$ & $2,6 \%$ & $3,4 \%$ & $0,9 \%$ & $1,7 \%$ \\
\hline AM & $0,8 \%$ & $0,4 \%$ & $1,8 \%$ & $2,9 \%$ & $45,8 \%$ & $51,4 \%$ & $30,5 \%$ & $19,9 \%$ & $1,8 \%$ & $1,0 \%$ & $14,1 \%$ & $21,1 \%$ & $5,3 \%$ & $3,3 \%$ \\
\hline AP & $0,5 \%$ & $0,6 \%$ & $1,6 \%$ & $1,2 \%$ & $91,3 \%$ & $92,2 \%$ & $0,5 \%$ & $1,2 \%$ & $0,5 \%$ & $0,6 \%$ & $1,6 \%$ & $1,8 \%$ & $3,8 \%$ & $2,4 \%$ \\
\hline BA & $1,0 \%$ & $1,4 \%$ & $19,7 \%$ & $11,6 \%$ & $21,6 \%$ & $30,9 \%$ & $0,6 \%$ & $1,4 \%$ & $44,5 \%$ & $43,8 \%$ & $9,1 \%$ & $7,9 \%$ & $3,5 \%$ & $3,0 \%$ \\
\hline CE & $4,9 \%$ & $3,7 \%$ & $1,2 \%$ & $2,1 \%$ & $2,0 \%$ & $2,1 \%$ & $6,1 \%$ & $4,3 \%$ & $67,2 \%$ & $75,0 \%$ & $16,6 \%$ & $11,7 \%$ & $2,0 \%$ & $1,1 \%$ \\
\hline DF & $0,2 \%$ & $0,2 \%$ & $64,0 \%$ & $72,3 \%$ & $3,8 \%$ & $3,9 \%$ & $0,2 \%$ & $0,8 \%$ & $28,5 \%$ & $18,8 \%$ & $1,0 \%$ & $1,9 \%$ & $2,3 \%$ & $2,1 \%$ \\
\hline ES & $1,8 \%$ & $0,7 \%$ & 8,9\% & $5,8 \%$ & $18,8 \%$ & $25,8 \%$ & $42,9 \%$ & $36,9 \%$ & $5,3 \%$ & $5,4 \%$ & $10,6 \%$ & $15,3 \%$ & $11,7 \%$ & $10,2 \%$ \\
\hline G0 & $0,1 \%$ & $0,4 \%$ & $22,6 \%$ & $28,3 \%$ & $10,1 \%$ & $11,9 \%$ & $0,4 \%$ & $0,3 \%$ & $59,5 \%$ & $53,3 \%$ & $1,8 \%$ & $3,4 \%$ & $5,5 \%$ & $2,5 \%$ \\
\hline MA & $0,4 \%$ & $1,6 \%$ & $2,8 \%$ & $4,8 \%$ & $79,2 \%$ & $77,5 \%$ & $2,1 \%$ & $0,0 \%$ & $0,7 \%$ & $0,5 \%$ & $7,1 \%$ & $9,1 \%$ & $7,8 \%$ & $6,4 \%$ \\
\hline $1 G$ & $1,1 \%$ & $0,8 \%$ & $13,8 \%$ & $16,5 \%$ & $6,6 \%$ & $14,2 \%$ & $0,4 \%$ & $0,5 \%$ & $64,2 \%$ & $52,7 \%$ & $11,2 \%$ & $12,1 \%$ & $2,6 \%$ & $3,2 \%$ \\
\hline MS & $0,3 \%$ & $1,0 \%$ & $10,8 \%$ & $9,4 \%$ & $1,7 \%$ & $8,1 \%$ & $0,3 \%$ & $0,7 \%$ & $75,7 \%$ & $65,4 \%$ & $6,6 \%$ & $9,7 \%$ & $4,5 \%$ & $5,7 \%$ \\
\hline MT & $0,4 \%$ & $1,0 \%$ & $64,1 \%$ & $67,9 \%$ & $11,8 \%$ & $11,5 \%$ & $0,6 \%$ & $0,0 \%$ & $12,7 \%$ & $12,8 \%$ & $3,0 \%$ & $1,7 \%$ & $7,4 \%$ & $5,0 \%$ \\
\hline PA & $3,7 \%$ & $2,4 \%$ & $22,7 \%$ & $23,3 \%$ & $48,3 \%$ & $53,2 \%$ & $0,4 \%$ & $0,8 \%$ & $9,2 \%$ & $6,1 \%$ & $9,2 \%$ & $8,9 \%$ & $6,6 \%$ & $5,3 \%$ \\
\hline PB & $0,2 \%$ & $0,5 \%$ & $30,5 \%$ & $26,8 \%$ & $57,4 \%$ & $61,0 \%$ & $0,2 \%$ & $0,5 \%$ & $5,7 \%$ & $6,2 \%$ & $4,2 \%$ & $3,1 \%$ & $1,7 \%$ & $1,9 \%$ \\
\hline PE & $0,3 \%$ & $0,4 \%$ & $2,3 \%$ & $1,3 \%$ & $2,9 \%$ & $5,4 \%$ & $16,4 \%$ & $12,1 \%$ & $66,7 \%$ & $62,5 \%$ & $9,0 \%$ & $16,1 \%$ & $2,4 \%$ & $2,2 \%$ \\
\hline $\mathrm{PI}$ & $1,6 \%$ & $0,7 \%$ & $54,5 \%$ & $33,6 \%$ & $19,1 \%$ & $48,3 \%$ & $7,6 \%$ & $3,1 \%$ & $9,9 \%$ & $6,6 \%$ & $4,8 \%$ & & $2,5 \%$ & $1,7 \%$ \\
\hline PR & $0,4 \%$ & $0,8 \%$ & $81,6 \%$ & $78,3 \%$ & $6,3 \%$ & $10,6 \%$ & $0,2 \%$ & $0,1 \%$ & $8,1 \%$ & $5,7 \%$ & $1,0 \%$ & $1,1 \%$ & $2,3 \%$ & $3,4 \%$ \\
\hline RJ & $1,4 \%$ & $2,3 \%$ & $26,5 \%$ & $21,3 \%$ & $42,3 \%$ & $27,5 \%$ & $11,9 \%$ & $32,2 \%$ & $7,3 \%$ & $4,6 \%$ & $5,5 \%$ & $7,1 \%$ & $5,2 \%$ & $5,0 \%$ \\
\hline RN & $0,5 \%$ & $1,0 \%$ & $78,6 \%$ & $80,1 \%$ & $8,8 \%$ & $8,6 \%$ & $0,2 \%$ & $0,0 \%$ & $5,0 \%$ & $5,8 \%$ & $1,7 \%$ & $1,4 \%$ & $5,2 \%$ & $3,1 \%$ \\
\hline RO & $0,8 \%$ & $0,4 \%$ & $75,4 \%$ & $82,1 \%$ & $9,0 \%$ & $8,6 \%$ & $0,4 \%$ & $0,0 \%$ & $9,8 \%$ & $7,1 \%$ & $1,2 \%$ & $0,4 \%$ & $3,3 \%$ & $1,5 \%$ \\
\hline $\mathrm{RR}$ & $0,0 \%$ & $0,0 \%$ & $4,8 \%$ & $2,0 \%$ & $76,2 \%$ & $75,8 \%$ & $1,9 \%$ & $0,0 \%$ & $0,0 \%$ & $0,0 \%$ & $4,8 \%$ & & $12,4 \%$ & $15,2 \%$ \\
\hline RS & $0,5 \%$ & $0,6 \%$ & $85,4 \%$ & $77,3 \%$ & $3,9 \%$ & $10,1 \%$ & $0,6 \%$ & $0,3 \%$ & $7,4 \%$ & $5,3 \%$ & $1,1 \%$ & $1,9 \%$ & $1,2 \%$ & $4,4 \%$ \\
\hline SC & $0,5 \%$ & $0,6 \%$ & $1,0 \%$ & $7,4 \%$ & $92,7 \%$ & $71,5 \%$ & $0,0 \%$ & $1,6 \%$ & $0,5 \%$ & $2,5 \%$ & $3,1 \%$ & $9,3 \%$ & $2,3 \%$ & $7,1 \%$ \\
\hline SE & $0,4 \%$ & $1,6 \%$ & $1,5 \%$ & $6,1 \%$ & $94,8 \%$ & $55,7 \%$ & $0,4 \%$ & $0,8 \%$ & $1,1 \%$ & $28,0 \%$ & $0,7 \%$ & $6,5 \%$ & $1,1 \%$ & $1,2 \%$ \\
\hline SP & $45,0 \%$ & $38,1 \%$ & $1,0 \%$ & $0,8 \%$ & $17,0 \%$ & $19,7 \%$ & $6,3 \%$ & $10,3 \%$ & $1,1 \%$ & $0,6 \%$ & $4,1 \%$ & $4,5 \%$ & $25,5 \%$ & $25,9 \%$ \\
\hline T0 & $0,5 \%$ & $0,3 \%$ & $1,9 \%$ & $0,6 \%$ & $74,7 \%$ & $88,3 \%$ & $5,1 \%$ & $0,3 \%$ & $1,6 \%$ & $0,0 \%$ & $5,6 \%$ & $3,5 \%$ & $10,5 \%$ & $7,0 \%$ \\
\hline$\sum$ & $10,8 \%$ & $9,6 \%$ & $26,3 \%$ & $26,3 \%$ & $22,9 \%$ & $24,2 \%$ & $4,4 \%$ & $5,5 \%$ & $21,6 \%$ & $19,0 \%$ & $5,4 \%$ & $6,5 \%$ & $8,6 \%$ & $9,0 \%$ \\
\hline
\end{tabular}

Nota: Os percentuais estão definidos por ano e por UF, totalizando $100 \%$.

Fonte: Elaborada pelos autores. 
RAP Efeito das políticas de provimento ao cargo de diretor na gestão escolar

\section{TABELA 4 ALPHA DE CRONBACH DO INDICADOR DE CLIMA ESCOLAR}

\begin{tabular}{cc} 
Itens & Alpha de Cronbach \\
\hline Sem TX_RESP_Q054 & 0,8166 \\
Sem TX_RESP_Q055 & 0,7844 \\
Sem TX_RESP_Q056 & 0,7767 \\
Sem TX_RESP_Q057 & 0,8194 \\
Todos os Itens & 0,8341 \\
\hline
\end{tabular}

Fonte: Elaborada pelos autores.

\section{TABELA 5 CORRELAÇÃO POLICÓRICA DOS ITENS DO INDICADOR DE CLIMA ESCOLAR}

\begin{tabular}{ccccc} 
Itens & TX_RESP_Q054 & TX_RESP_Q055 & TX_RESP_Q056 & TX_RESP_Q057 \\
\hline TX_RESP_Q054 & 1,0000 & 0,5625 & 0,4920 & 0,4675 \\
TX_RESP_Q055 & 0,5625 & 1,0000 & 0,6315 & 0,4997 \\
TX_RESP_Q056 & 0,4920 & 0,6315 & 1,0000 & 0,5732 \\
TX_RESP_Q057 & 0,4675 & 0,4997 & 0,5732 & 1,0000
\end{tabular}

Fonte: Elaborada pelos autores.

\section{GRÁFICO 6 AUTO VALORES DO INDICADOR DE CLIMA ESCOLAR}

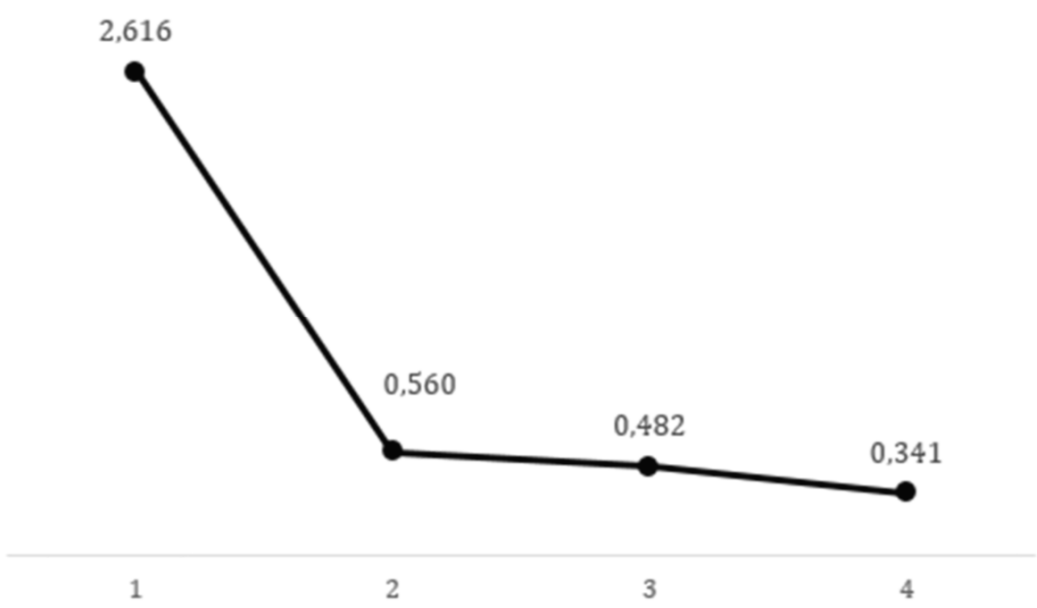

Fonte: Elaborado pelos autores. 
RAP | Efeito das políticas de provimento ao cargo de diretor na gestão escolar

\section{TABELA 6 PARÂMETRO DOS ITENS DO INDICADOR DE CLIMA ESCOLAR}

\begin{tabular}{cccccc} 
Itens & $\mathbf{a}$ & $\mathbf{b 1}$ & $\mathbf{b 2}$ & $\mathbf{b 3}$ & b4 \\
\hline TX_RESP_Q054 & 1,6120 & $-1,9880$ & $-1,4960$ & $-0,4870$ & 0,4370 \\
TX_RESP_Q055 & 2,3400 & $-1,7410$ & $-1,2770$ & $-0,3070$ & 0,5040 \\
TX_RESP_Q056 & 2,5060 & $-2,1820$ & $-1,6810$ & $-0,4620$ & 0,4890 \\
TX_RESP_Q057 & 1,7000 & $-2,0140$ & $-1,0680$ & 0,3620 & 1,5170 \\
\hline
\end{tabular}

Fonte: Elaborada pelos autores.

\section{GRÁFICO 7 CURVA CARACTERÍSTICA DO ITEM - INDICADOR DE CLIMA ESCOLAR}

Curva Característica do Item TX RESP Q054

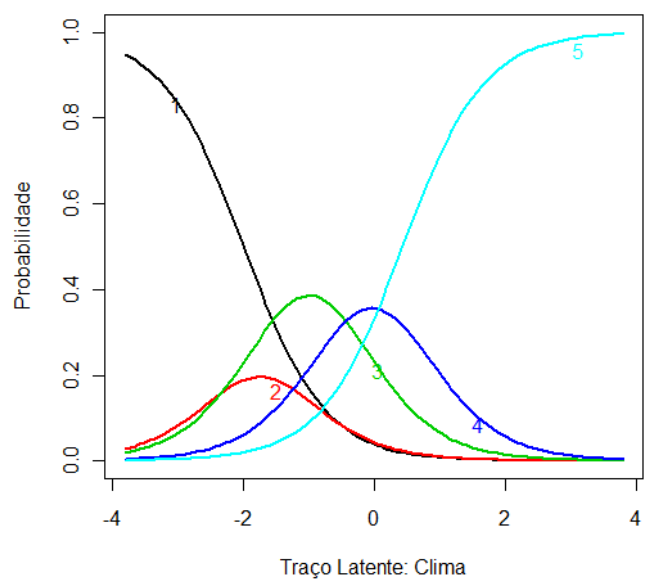

Curva Característica do Item TX_RESP_Q056

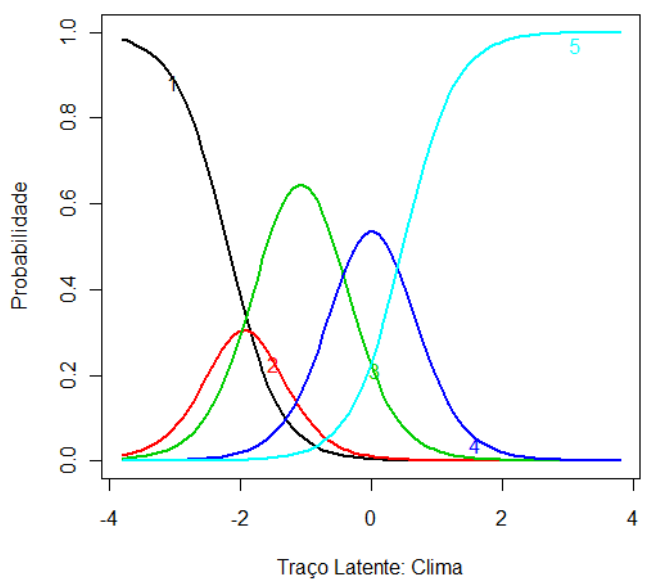

Curva Característica do Item TX_RESP Q055

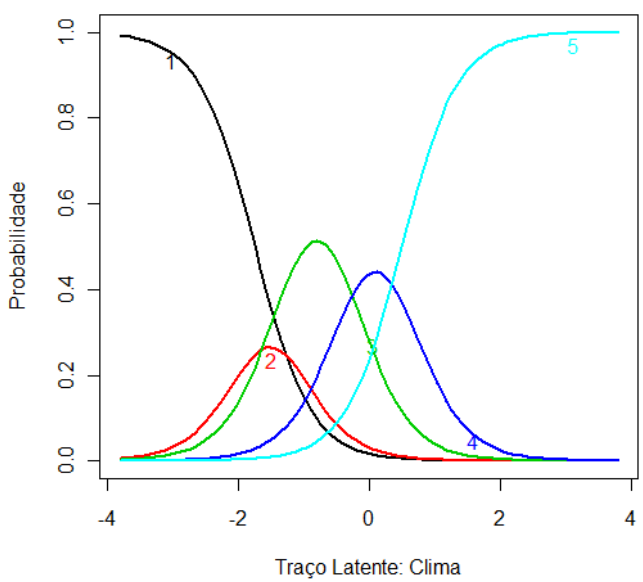

Curva Característica do Item TX_RESP_Q057

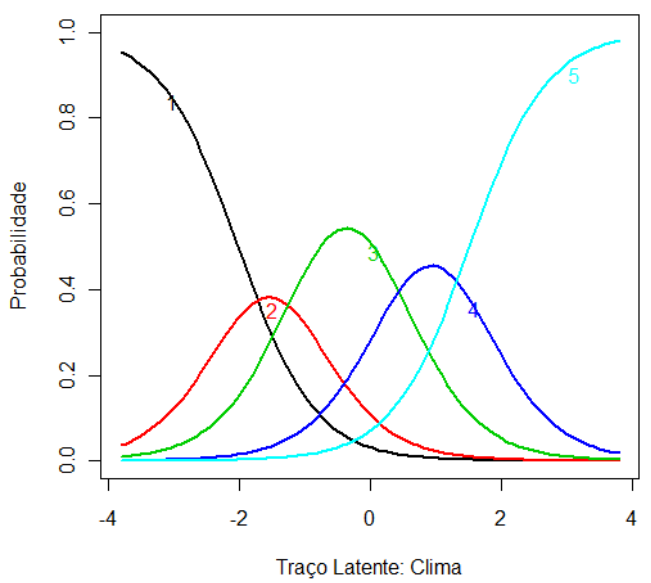

Nota: 1: opção A; 2: opção B; 3: opção C; 4: opção D; 5: opção E.

Fonte: Elaborado pelos autores. 


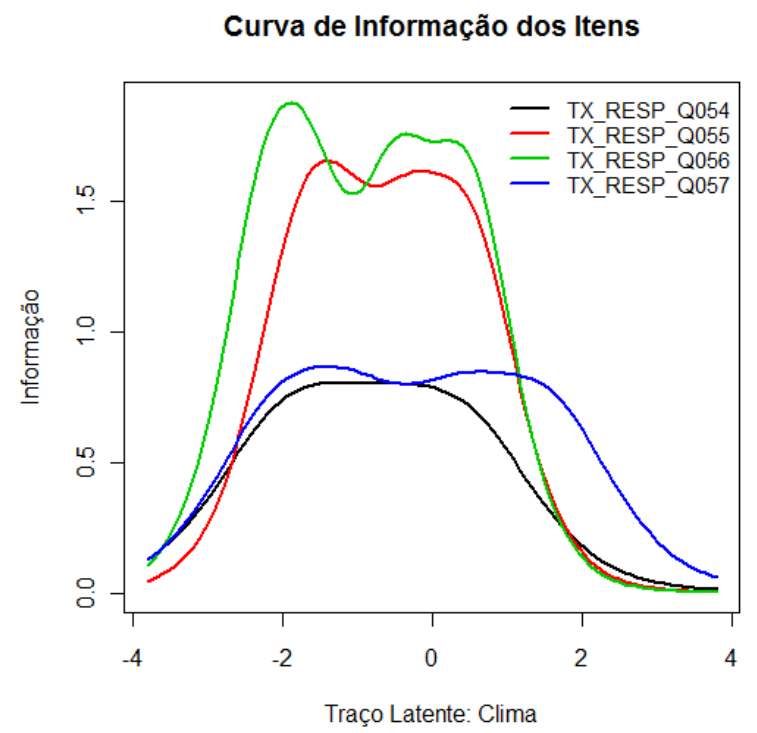

Fonte: Elaborado pelos autores.

GRÁFICO 9 CURVA DE INFORMAÇÃO DO TESTE - INDICADOR DE CLIMA ESCOLAR

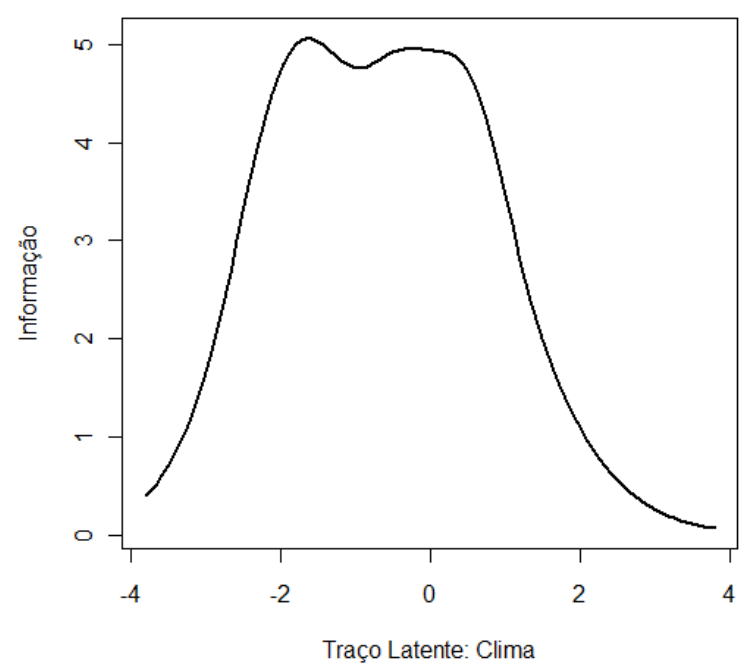

Fonte: Elaborado pelos autores. 
RAP | Efeito das políticas de provimento ao cargo de diretor na gestão escolar

TABELA 7 CURVA DE INFORMAÇÃO DO TESTE - INDICADOR DE CLIMA ESCOLAR

\begin{tabular}{cc} 
Itens & Alpha de Cronbach \\
\hline Sem TX_RESP_Q058 & 0,9446 \\
Sem TX_RESP_Q059 & 0,9431 \\
Sem TX_RESP_Q060 & 0,9454 \\
Sem TX_RESP_Q061 & 0,9388 \\
Sem TX_RESP_Q062 & 0,9423 \\
Sem TX_RESP_Q063 & 0,9425 \\
Sem TX_RESP_Q064 & 0,9403 \\
Sem TX_RESP_Q065 & 0,9407 \\
Sem TX_RESP_Q066 & 0,9443 \\
Sem TX_RESP_Q067 & 0,9414 \\
\hline Todos 0S Itens & 0,9476 \\
\hline
\end{tabular}

Fonte: Elaborada pelos autores.

\section{TABELA 8 CORRELAÇÃO POLICÓRICA DOS ITENS DO INDICADOR DE LIDERANÇA ESCOLAR}

\begin{tabular}{|c|c|c|c|c|c|}
\hline Itens & TX_RESP_Q058 & TX_RESP_Q059 & TX_RESP_Q060 & TX_RESP_Q061 & TX_RESP_Q062 \\
\hline TX_RESP_Q058 & 1,00000 & 0,75349 & 0,67630 & 0,73450 & 0,57447 \\
\hline TX_RESP_Q059 & 0,75349 & 1,00000 & 0,67483 & 0,73897 & 0,63186 \\
\hline TX_RESP_Q060 & 0,67630 & 0,67483 & 1,00000 & 0,72424 & 0,60808 \\
\hline TX_RESP_Q061 & 0,73450 & 0,73897 & 0,72424 & 1,00000 & 0,73018 \\
\hline TX_RESP_Q062 & 0,57447 & 0,63186 & 0,60808 & 0,73018 & 1,00000 \\
\hline TX_RESP_Q063 & 0,55931 & 0,60355 & 0,58450 & 0,69172 & 0,82456 \\
\hline TX_RESP_Q064 & 0,68184 & 0,64150 & 0,66834 & 0,75952 & 0,62780 \\
\hline TX_RESP_Q065 & 0,68919 & 0,64182 & 0,67645 & 0,75946 & 0,62141 \\
\hline TX_RESP_Q066 & 0,48683 & 0,53564 & 0,49699 & 0,61313 & 0,57907 \\
\hline TX_RESP_Q067 & 0,57391 & 0,59846 & 0,56447 & 0,70018 & 0,64360 \\
\hline Itens & TX_RESP_Q063 & TX_RESP_Q064 & TX_RESP_Q065 & TX_RESP_Q066 & TX_RESP_Q067 \\
\hline TX_RESP_Q058 & 0,55931 & 0,68184 & 0,68919 & 0,48683 & 0,57391 \\
\hline TX_RESP_Q059 & 0,60355 & 0,64150 & 0,64182 & 0,53564 & 0,59846 \\
\hline TX_RESP_Q060 & 0,58450 & 0,66834 & 0,67645 & 0,49699 & 0,56447 \\
\hline
\end{tabular}


RAP | Efeito das políticas de provimento ao cargo de diretor na gestão escolar

\begin{tabular}{cccccc} 
Ittens & TX_RESP_Q063 & TX_RESP_Q064 & TX_RESP_Q065 & TX_RESP_Q066 & TX_RESP_Q067 \\
\hline TX_RESP_Q061 & 0,69172 & 0,75952 & 0,75946 & 0,61313 & 0,70018 \\
TX_RESP_Q062 & 0,82456 & 0,62780 & 0,62141 & 0,57907 & 0,64360 \\
TX_RESP_Q063 & 1,00000 & 0,65375 & 0,63862 & 0,59968 & 0,66572 \\
TX_RESP_Q064 & 0,65375 & 1,00000 & 0,87104 & 0,68315 & 0,73895 \\
TX_RESP_Q065 & 0,63862 & 0,87104 & 1,00000 & 0,64551 & 0,70938 \\
TX_RESP_Q066 & 0,59968 & 0,68315 & 0,64551 & 1,00000 & 0,84357 \\
TX_RESP_Q067 & 0,66572 & 0,73895 & 0,70938 & 0,84357 & 1,00000 \\
\hline
\end{tabular}

Fonte: Elaborada pelos autores.

\section{GRÁFICO 10 AUTO VALORES DO INDICADOR DE LIDERANÇA ESCOLAR}

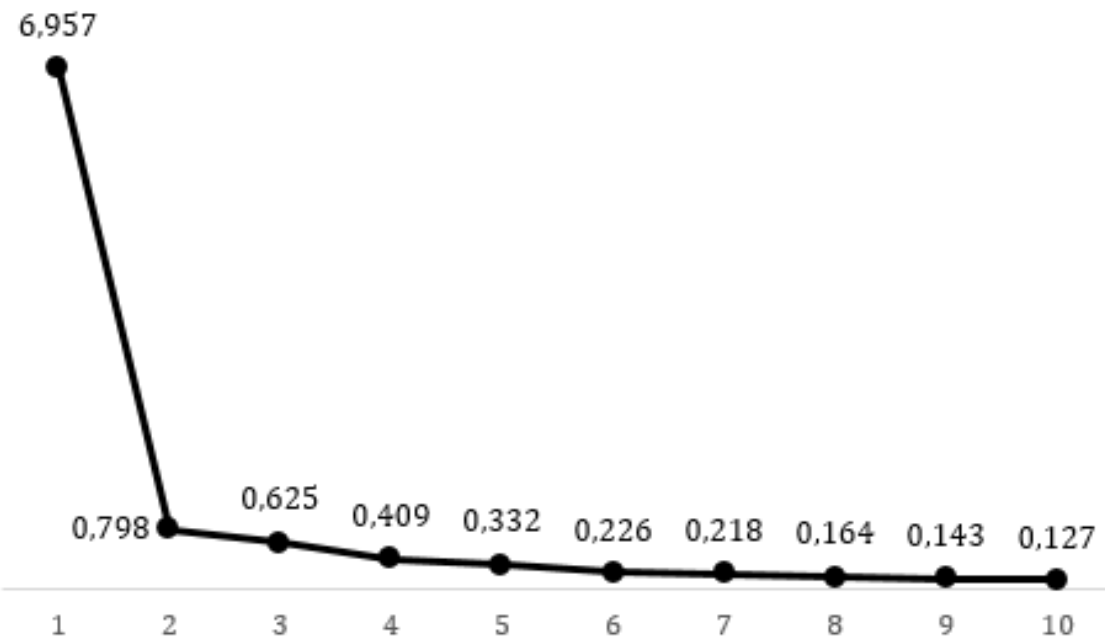

Fonte: Elaborado pelos autores.

TABELA 9 PARÂMETRO DOS ITENS DO INDICADOR DE LIDERANÇA ESCOLAR

\begin{tabular}{ccccc} 
Itens & a & b1 & b2 & b3 \\
\hline TX_RESP_Q058 & 2,3570 & $-1,9000$ & $-0,3140$ & 0,9670 \\
TX_RESP_Q059 & 2,4120 & $-2,3400$ & $-0,9080$ & 0,5260 \\
TX_RESP_Q060 & 2,2850 & $-1,7170$ & $-0,4270$ & 0,7180 \\
TX_RESP_Q061 & 3,6420 & $-1,8150$ & $-0,6260$ & 0,5110 \\
TX_RESP_Q062 & 2,4400 & $-2,6300$ & $-1,1820$ & 0,3450 \\
\hline & & & & Continua
\end{tabular}


RAP | Efeito das políticas de provimento ao cargo de diretor na gestão escolar

\begin{tabular}{ccccc}
\hline Itens & a & b1 & b2 & b3 \\
\hline TX_RESP_Q063 & 2,3860 & $-2,6730$ & $-1,1910$ & 0,3130 \\
TX_RESP_Q064 & 3,5080 & $-1,4390$ & $-0,3630$ & 0,5940 \\
TX_RESP_Q065 & 3,3720 & $-1,4950$ & $-0,3610$ & 0,6050 \\
TX_RESP_Q066 & 2,0770 & $-2,6280$ & $-1,3510$ & $-0,0420$ \\
TX_RESP_Q067 & 2,6920 & $-2,2360$ & $-1,0960$ & 0,0150
\end{tabular}

Fonte: Elaborada pelos autores.

\section{GRÁFICO 11 CURVA CARACTERÍSTICA DO ITEM - INDICADOR DE LIDERANÇA ESCOLAR}

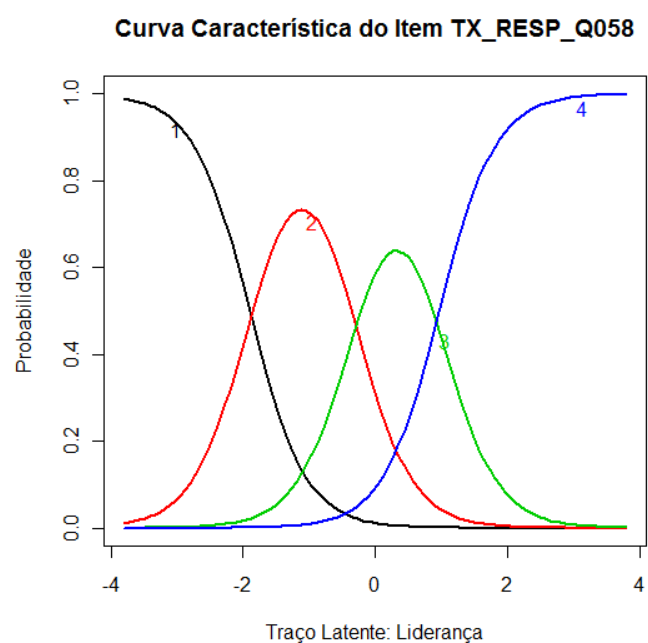

Curva Característica do Item TX_RESP_Q060

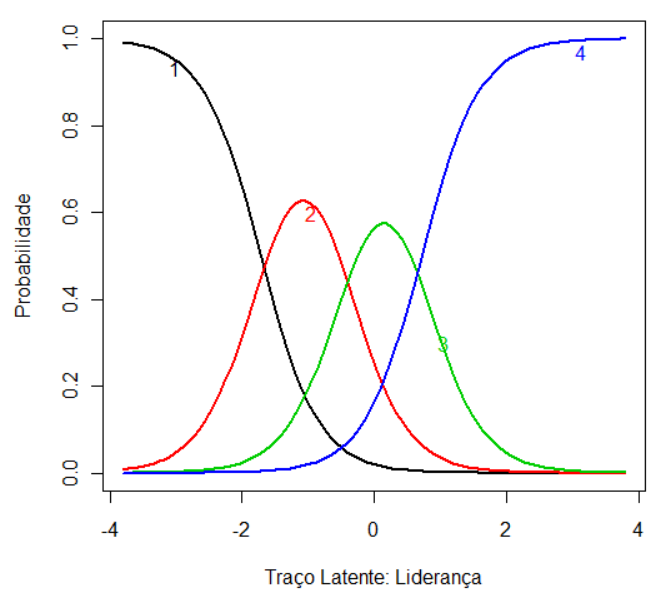

Curva Característica do Item TX_RESP_Q059

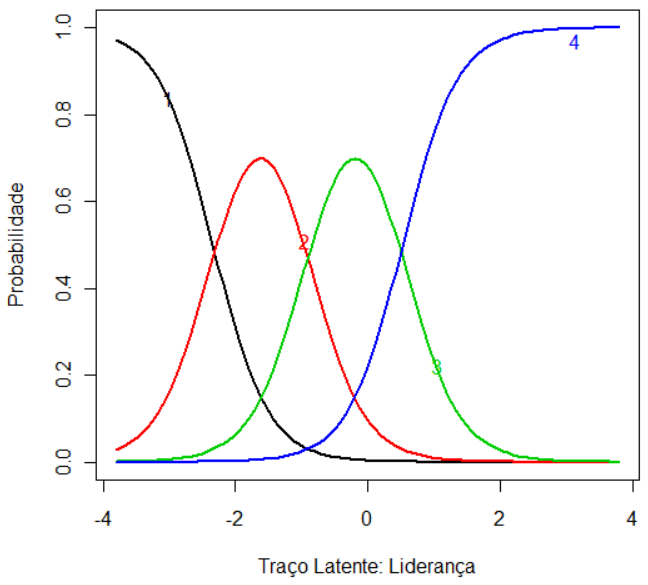

Curva Característica do Item TX_RESP_Q061

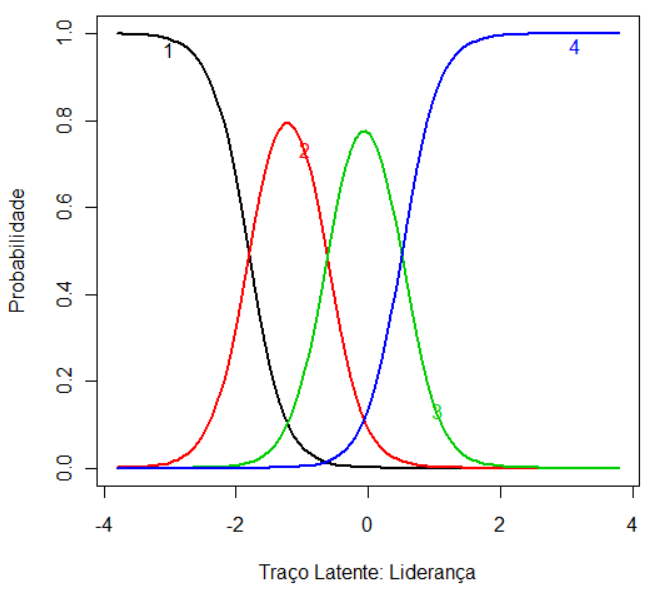

Continua 
Curva Característica do Item TX_RESP_Q062

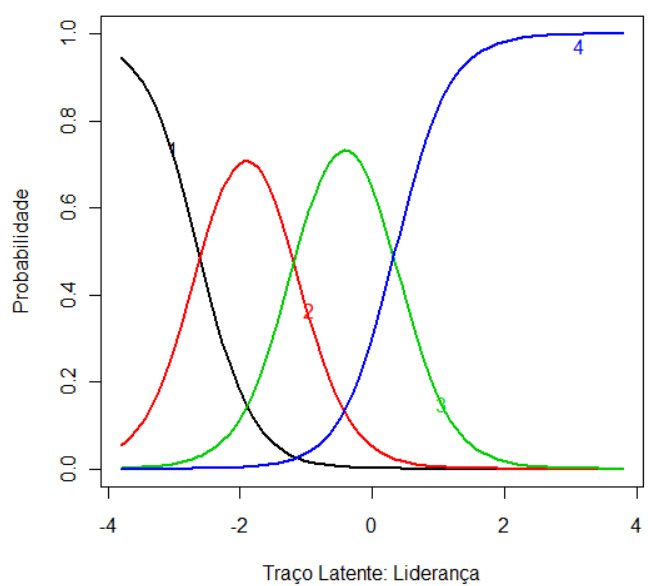

Curva Característica do Item TX_RESP_Q064

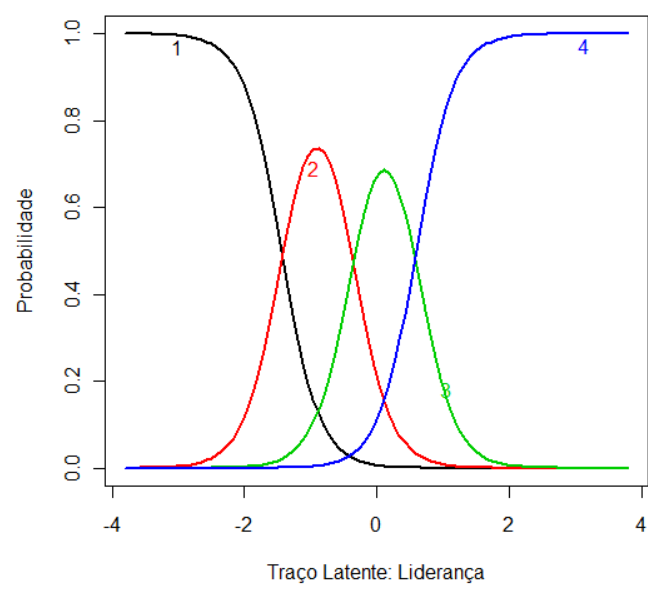

Curva Característica do Item TX RESP Q066

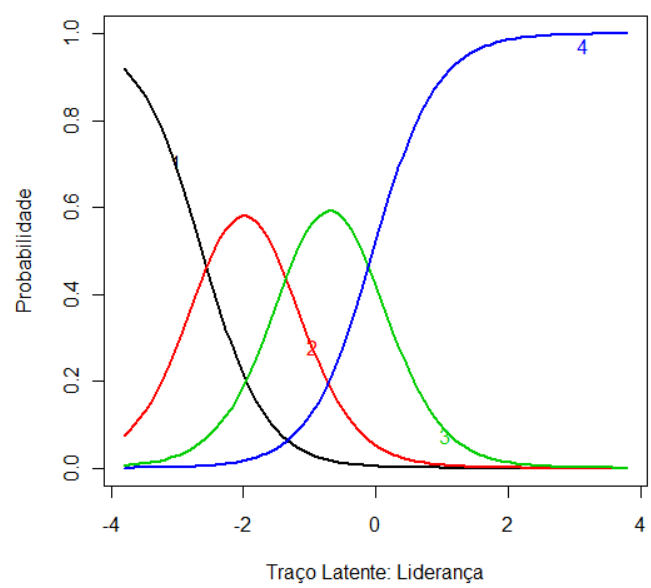

Curva Característica do Item TX RESP_Q063

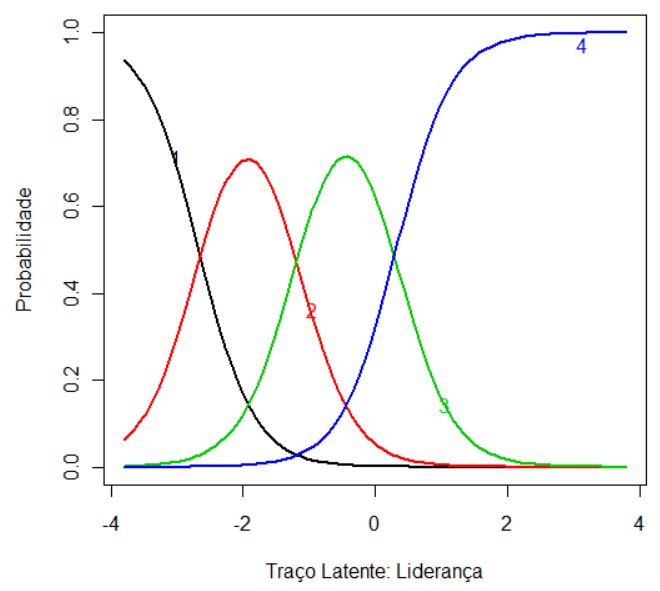

Curva Característica do Item TX RESP Q065

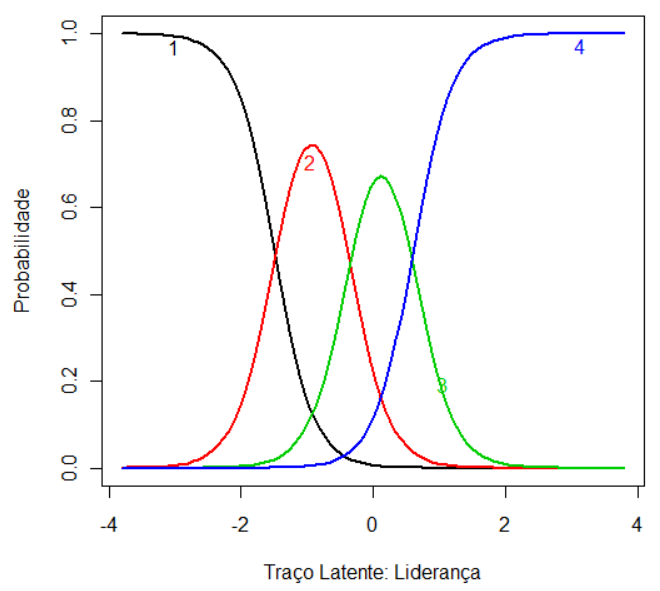

Curva Característica do Item TX_RESP_Q067

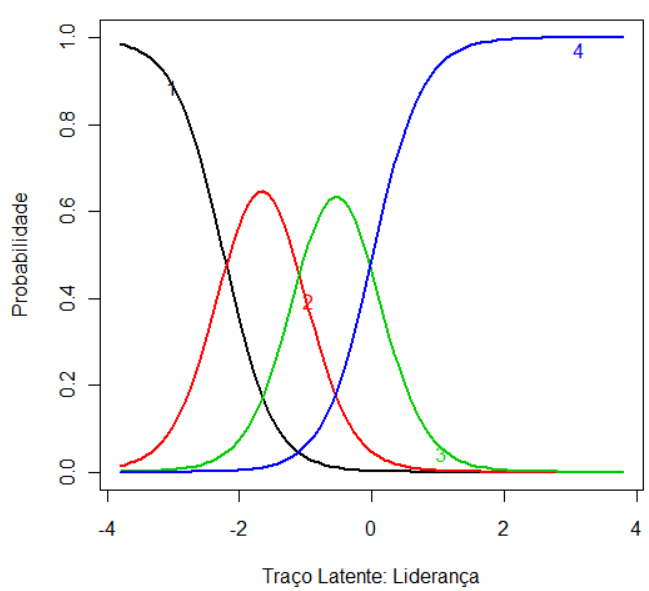

Nota: 1: opção A; 2: opção B; 3: opção C; 4: opção D.

Fonte: Elaborado pelos autores. 


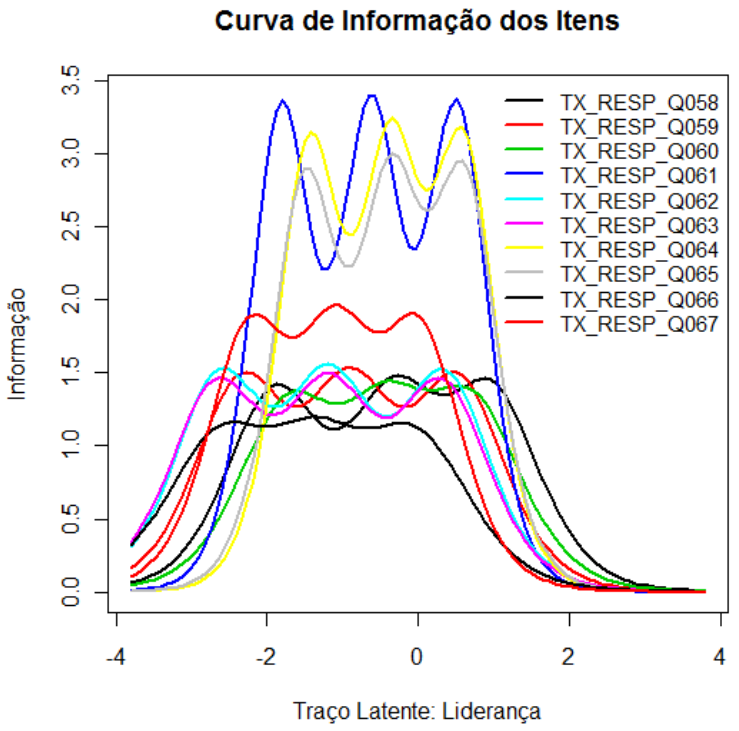

Fonte: Elaborado pelos autores.

GRÁFICO 13 CURVA DE INFORMAÇÃO DO TESTE - INDICADOR DE LIDERANÇA ESCOLAR

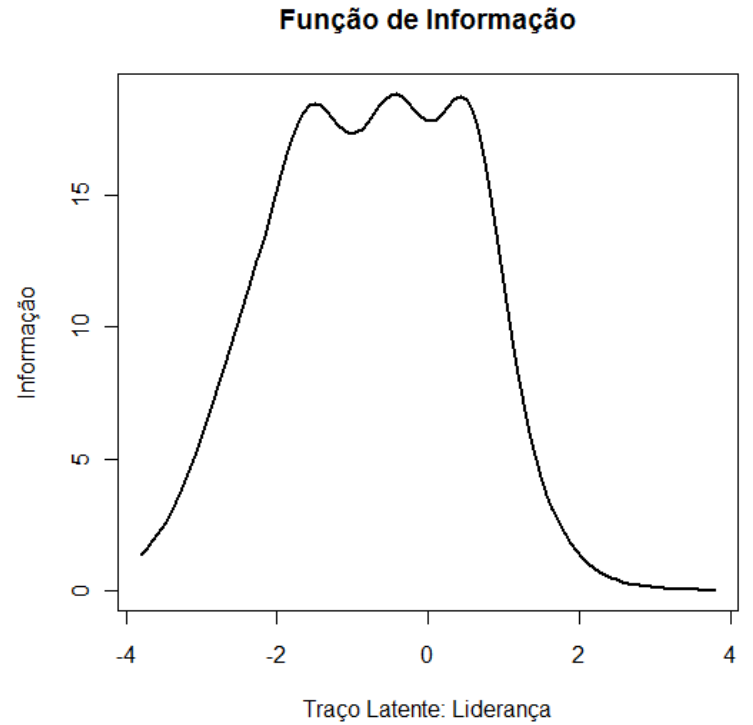

Fonte: Elaborado pelos autores. 


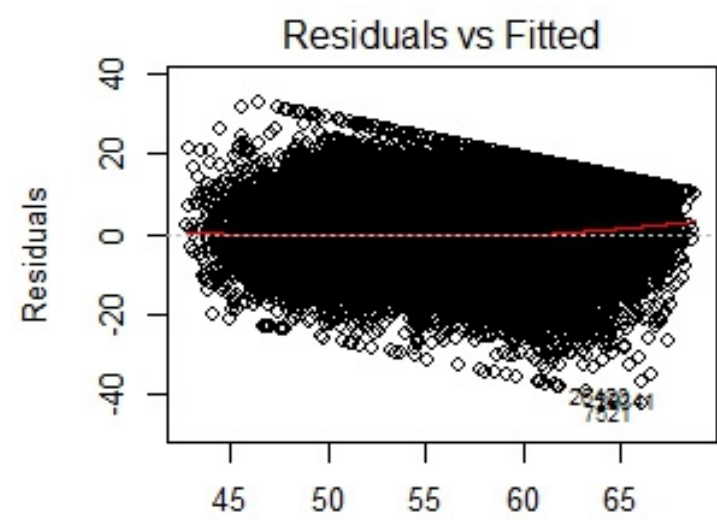

Fitted values

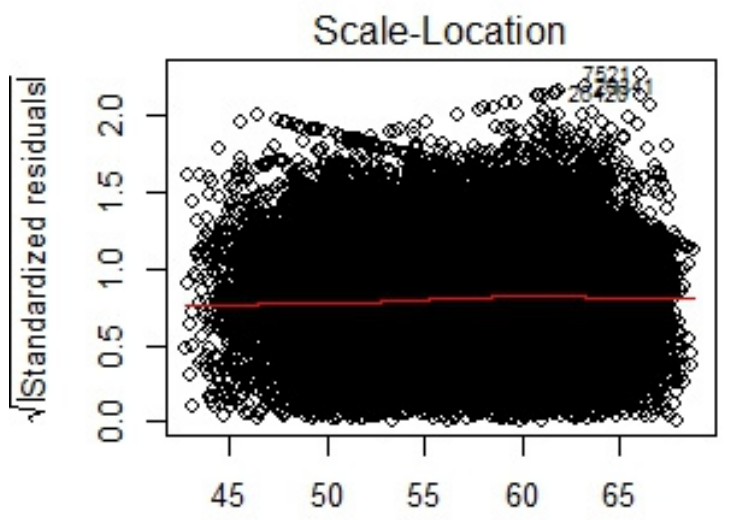

Fitted values
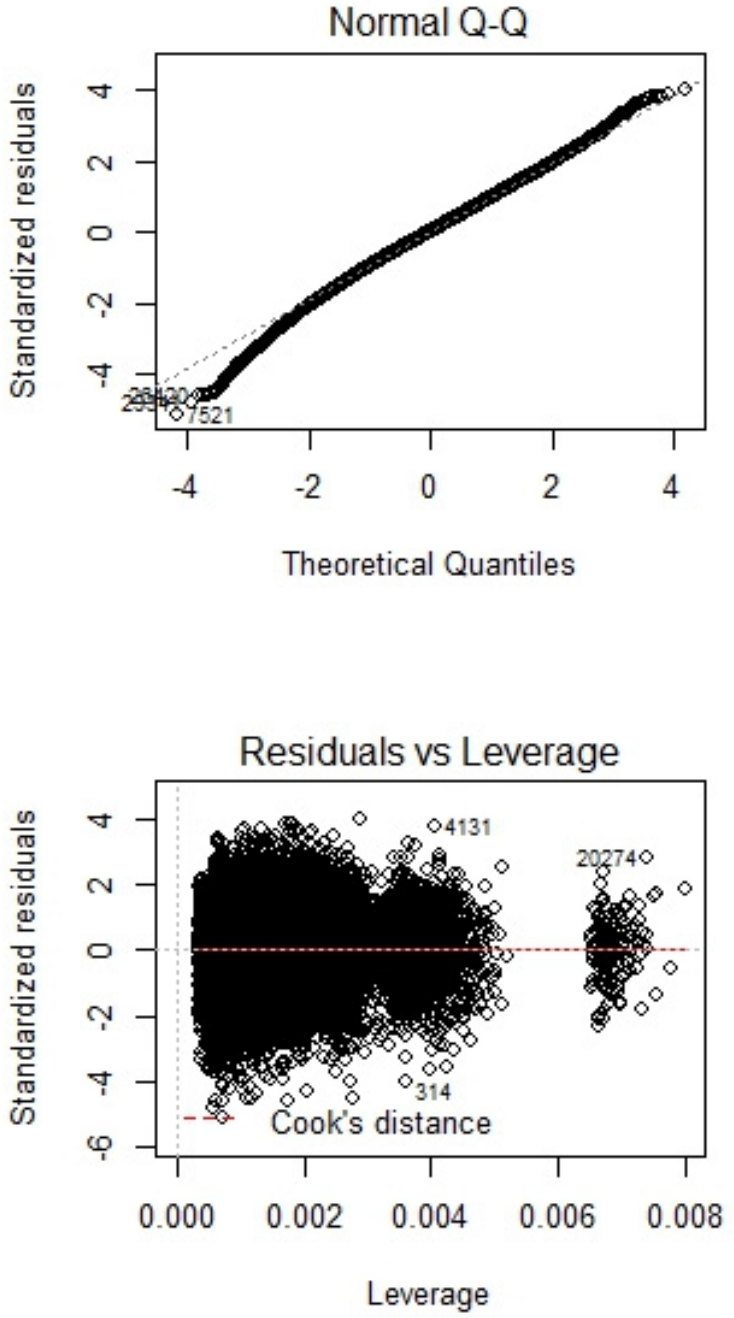

Fonte: Elaborado pelos autores. 


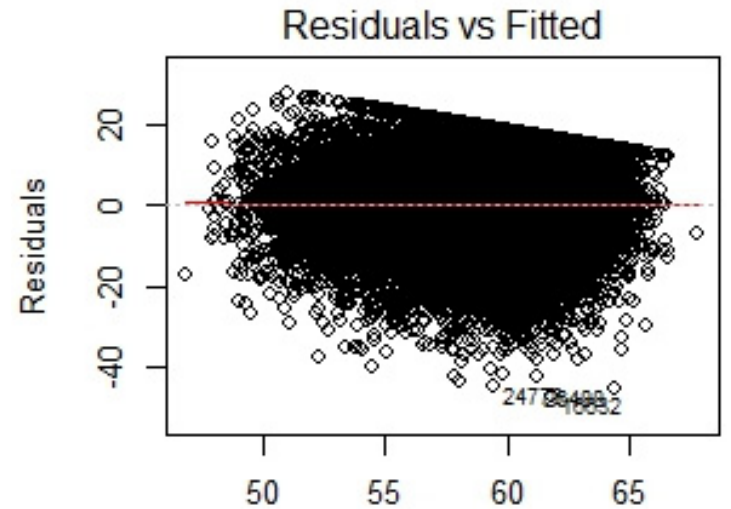

Fitted values

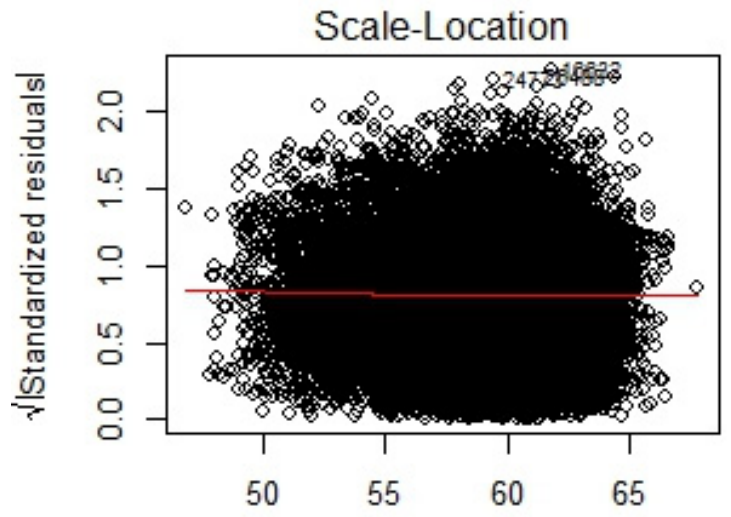

Fitted values
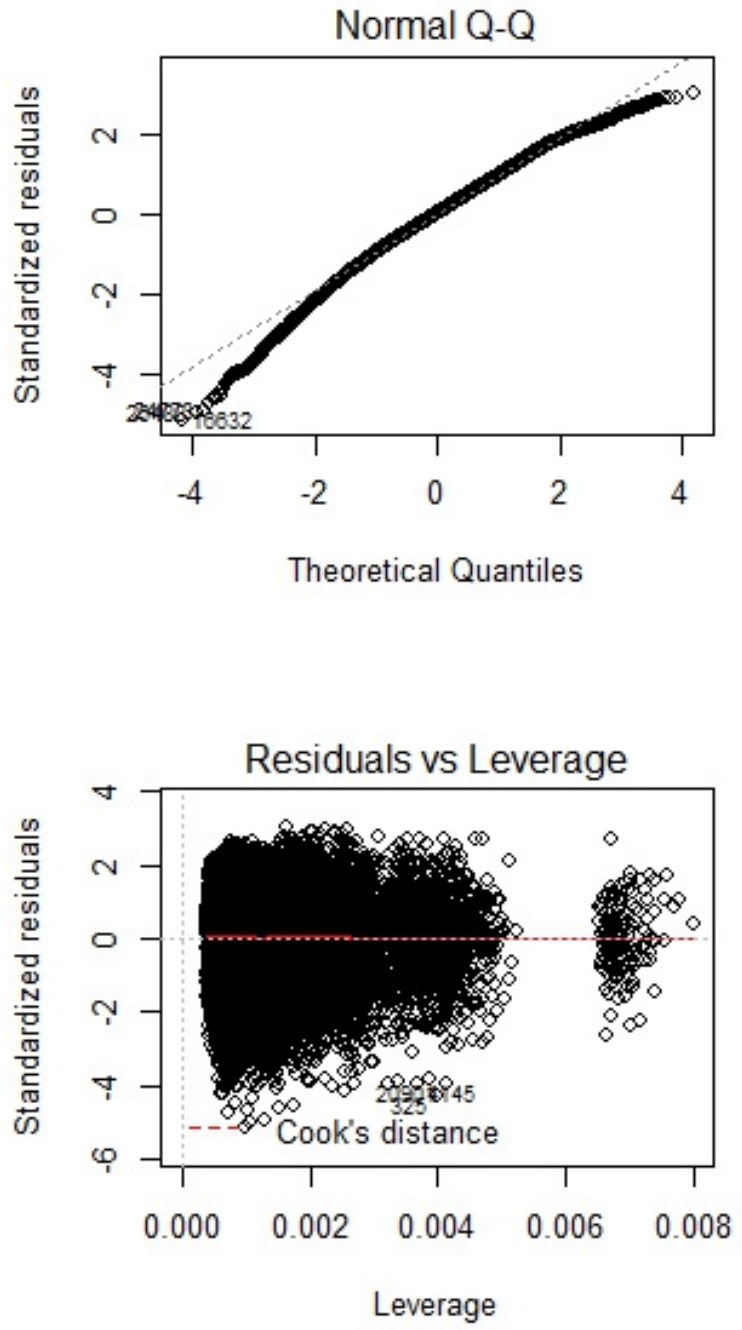

Fonte: Elaborado pelos autores. 